\title{
The planktonic food web of the Bizerte lagoon (south-western Mediterranean) during summer: I. Spatial distribution under different anthropogenic pressures
}

\author{
Asma Sakka Hlaili ${ }^{a}{ }^{*}$, Boutheina Grami ${ }^{a}{ }^{b}$, Nathalie Niquil ${ }^{b}$, Michel Gosselin ${ }^{c}$, Dominique \\ Hamel $^{\mathrm{c}}$, Marc Troussellier ${ }^{\mathrm{d}}$ and Hassine Hadj Mabrouk ${ }^{\mathrm{a}}$
}

\footnotetext{
a Laboratoire de cytologie végétale et phytoplanctonologie, Faculté des Sciences de Bizerte, 7021 Zarzouna, Bizerte, Tunisia

${ }^{\mathrm{b}}$ Centre de recherche sur les écosystèmes littoraux anthropisés, UMR 6217, CNRS-IFREMER-Université de La Rochelle, Av. Michel Crépeau, 17042 La Rochelle Cedex 1, France

${ }^{c}$ Institut des sciences de la mer de Rimouski (ISMER), Université du Québec à Rimouski, 310 allée des Ursulines, Rimouski, Québec G5L 3A1, Canada

d UMR 5119, CNRS-Université Montpellier II-Ifremer, Case 093, Place Eugène Bataillon, 34095 Montpellier Cedex 5, France
}

*: Corresponding author : Asma Sakka, email address : asma sakka@yahoo.fr

\begin{abstract}
:
The structure and the trophic interactions of the planktonic food web were investigated during summer 2004 in a coastal lagoon of south-western Mediterranean Sea. Biomasses of planktonic components as well as bacterial and phytoplankton production and grazing by microzooplankton were quantified at four stations (MA, MB, MJ and R) inside the lagoon. Station MA was impacted by urban discharge, station MB was influenced by industrial activity, station MJ was located in a shellfish farming sector, while station $\mathrm{R}$ represented the lagoon central area. Biomasses and production rates of bacteria (7-33 $\mathrm{mg} \mathrm{C} \mathrm{m}{ }^{-3}$; 17.5-35 $\mathrm{mg} \mathrm{C} \mathrm{m}^{-3} \mathrm{~d}^{-1}$ ) and phytoplankton (80-299 $\mathrm{mg} \mathrm{C} \mathrm{m}^{-3} ; 34-210 \mathrm{mg} \mathrm{C} \mathrm{m}^{-3} \mathrm{~d}^{-1}$ ) showed high values at station $\mathrm{MJ}$, where substantial concentrations of nutrients ( $\mathrm{NO} 3-$ and $\mathrm{Si}(\mathrm{OH}) 4$ ) were found. Microphytoplankton, which dominated the total algal biomass and production $(>82 \%)$, were characterized by the proliferation of several chain-forming diatoms. Microzooplankton was mainly composed of dinoflagellates (Torodinium, Protoperidinium and Dinophysis) and aloricate (Lohmaniellea and Strombidium) and tintinnid (Tintinnopsis, Tintinnus, Favella and Eutintinnus) ciliates. Higher biomass of these protozoa $\left(359 \mathrm{mg} \mathrm{C} \mathrm{m}^{-3}\right)$ was observed at station MB, where large tintinnids were encountered. Mesozooplankton mainly represented by Calanoida (Acartia, Temora, Calanus, Eucalanus, Paracalanus and Centropages) and Cyclopoida (Oithona) copepods, exhibited higher and lower biomasses at stations MA/MJ and MB, respectively. Bacterivory represented only $35 \%$ of bacterial production at stations MB and R, but higher fractions (65-70\%) were observed at stations MA and MJ. Small heterotrophic flagellates and aloricate ciliates seemed to be the main controllers of bacteria. Pico- and nanophytoplankton represented a significant alternative carbon pool for micrograzers, which grazing represented $67-90 \%$ of pico- and nano-algal production in all stations. Microzooplankton has, however, a relatively low impact on microphytoplankton, as $\leq 45 \%$ of microalgal production was consumed in all stations. This implies that an important fraction of diatom production would be channelled by herbivorous meso-grazers to higher consumers at stations MA and MJ where copepods were numerous. Most of the microalgal production would, however, sink particularly at station MB where copepods were scare. These different trophic interactions suggest different food web structures between stations. A multivorous food web seemed to prevail in stations MJ and MA, whereas microbial web was dominant in the other stations.
\end{abstract}

Keywords: Mediterranean lagoon; planktonic food web; spatial distribution; anthropogenic pressure 


\section{Introduction}

During the last decades, our perception of the marine food webs has change since microbial loop and herbivorous web are not usually the only important pathways of $C$ transfer, but the more complex microbial and multivorous webs are present in aquatic environments (Azam et al., 1983; Legendre and Rassoulzadegan, 1995). The type of food web influences the fate of biogenic carbon in different ways. The herbivorous and multivorous webs generally dominate in eutrophic waters where allochthonous nutrient inputs sustain high new production and abundances of large algae and zooplankton are high. Then, the algal production is readily channelling to large consumers or exported to deep water via fast-sinking metazoan fecal pellets and mass sinking of cell agregats (Michel et al., 2002; Turner, 2002). In oligotrophic environments dominated by microbial food webs, most of the nutrients necessary to sustain primary production are recycled through grazing of protozoa on picoplankton (Goldman et al., 1987). In this case, a major fraction of biogenic carbon may be lost to multiple trophic transfers and remineralized within the euphotic zone. Nevertheless, there is increasing evidence that microbial food webs may play a significant role in carbon export since microzooplankton can act as a significant link between small producers and large consumers (Vézina and Platt, 1988; Nielsen et al., 1993). Indeed, heterotrophic nanoflagellates and small ciliates are significant grazers of pico- and nanoalgae (Šimek et al., 1995; Sakka et al., 2000) and they may affect the size structure of bacterial assemblage (Calbet et al., 2001; Bouvy et al., 2006). Heterotrophic dinoflagellates and large ciliates can control the bacterivorous flagellates (Lessard and Swift, 1985; Strom and Morello, 1998) and in the same time provide an essential food supply for mesozooplankton (Calbet and Landry, 1999; Calbet and Saiz, 2005).

Relatively little is known about the planktonic food webs in Mediterranean coastal lagoons. These areas are generally characterized by weak exchange with the sea waters and subjected to recurrent eutrophication, which is caused by increased nutrient loading from expanding anthropogenic activities (De Casabianca et al., 1997; Solidoro et al., 2005). Moreover, several lagoons develop intensive shellfish farming that contribute to an additional source of nutrients in these areas. The rapid change in nutrient status would influence the community structures of phytoplankton and hence of the other trophic components. Because of the alterations in planktonic communities of these lagoons, the structure and the functioning of their food webs became a focus of interest. Mediterranean lagoons sustain higher levels of phytoplankton biomass and production (Flindt et al., 1997; Bec et al., 2005). In these eutrophic systems, diatom blooms may occur mainly in spring and summer (Gilabert, 2001; Nuccio et al., 2003) and copepods are generally the main metazoan zooplankton (Lam-Hoai and Rougier, 2001; Hamdi et al., 2002). This may suggest the significance of the herbivorous pathway in carbon transfer. Moreover, high densities of heterotrophic flagellates and ciliates reported in several Mediterranean lagoons (Rougier and Lam-Hoai, 1997; Daly Yahia et al., 2005; Sakka Hlaili et al., 2007) may indicate the significance of the microbivory. Thus, the dominance of the multivorous food wed is expected in these regions.

The lagoon of Bizerte, on the south-western border of the Mediterranean Sea, is considered to have undergone eutrophication and develops an intensive shellfish farming (mussels, oysters and clams) that supplies an annual production $>100$ tons, (Khessiba et al., 2001). In this lagoon, several studies have investigated the various planktonic compartments in separated manner [e.g. phytoplankton (Sakka Hlaili et al., 2006); metazooplankton (Hamdi et al., 2002)]. This could seriously limit our knowledge of the structure for the planktonic food web and its response to anthropogenic expanding pressure. The present study is positioned in the context of a future functional modelling. It proposes to analyze, for the first time in the Bizerte lagoon, the interactions of different planktonic food web components as well as the grazing impact of microzooplankton on bacterial and phytoplankton production. The study was carried out during summer, a season characterized by high phytoplankton and microzooplankton biomasses and significant diatom proliferation (Sakka Hlaili et al., 2007).

\section{Material and methods}

\subsection{Study site}

The Bizerte Lagoon $\left(37^{\circ} 8^{\prime}-37^{\circ} 14^{\prime} \mathrm{N}, 9^{\circ} 48^{\prime}-9^{\circ} 56^{\prime} \mathrm{E}\right.$, Fig. 1) has an average depth of $8 \mathrm{~m}$, a volume of $851.210^{6} \mathrm{~m}^{3}$ and an area of $121.6 \mathrm{~km}^{2}$ (Mzoughi et al., 2002) that makes it the third important lagoon in Tunisia. A 7-km long channel (300 m width and $12 \mathrm{~m}$ depth) connects the lagoon to the sea. The marine inflow is strong in summer (Harzallah, 2003). Under windless condition, a semidiurnal tide 
(0.02-0.13 $\mathrm{m}$ of amplitude) requires more than one year to renew the total water volume of the lagoon. Temporal freshwater supplies $\left(20 \mathrm{Mm}^{3} \mathrm{yr}^{-1}\right)$ are from several surrounding rivers and mainly from Lake Ichkeul through the Tinja river (Harzallah, 2003). The lagoon hydrodynamics is mainly driven by wind forces that exhibit a defined seasonal pattern with a dominance of winds from the east $\left(5 \mathrm{~m} \mathrm{~s}^{-1}\right.$ in summer) and northwest $\left(8 \mathrm{~m} \mathrm{~s}^{-1}\right.$ in winter). During summer, the season of our sampling, the hydrodynamics of the lagoon is characterized by an anticyclonic gyre in the North and a cyclonic circulation in the South. The wind renewal time of water body could reach several months. Water temperature and salinity range from 12 to $28^{\circ} \mathrm{C}$ and from 32 to 38 , respectively. The bottom of the western and eastern sectors of the lagoon is essentially made of sands while silt deposits occur particularly in the centre of the system (Harzallah, 2003). From a morphological and hydrodynamic point of view, the study site can be classified as a restricted lagoon (Gamito et al., 2005).

\subsection{Sampling}

The sampling was carried out in summer 2004 (from 13 to 20 July) at 4 stations (Fig. 1). The characteristics of stations and sampling dates and depths in each one are given in Table 1 . The vertical attenuation coefficient for the downward irradiance was measured with a Secchi disk (Holmes, 1970). Water temperature and salinity were measured in situ with a microprocessor conductivity meter (Wissenschaftlich-Technische-Werkstatten (WTW) LF 196). Water was collected using an acidwashed 2.5 I plastic water sampler PWS (Hydro-Bios), then filtered through a $200 \mu \mathrm{m}$ mesh screen. At each depth, several samples were taken for different laboratory analyses and stored in isothermal containers until they were processed. At each station, a vertical haul was taken from $4 \mathrm{~m}$ to surface, using $200 \mu \mathrm{m}$ mesh net, to determine the composition of mesozooplankton.

\subsection{Water sample analyses}

Samples for nutrients $(500 \mathrm{ml})$ were filtered through Whatman GF/F filters. The filtrates were collected in acid-washed vials and kept frozen $\left(-20^{\circ} \mathrm{C}\right)$ until analysis (within two weeks). Nutrient concentrations were determined by spectrophotometric methods $\left(\mathrm{NO}_{3}{ }^{-}\right.$and $\mathrm{NO}_{2}{ }^{-}$: Wood et al., 1967; $\mathrm{PO}_{4}{ }^{3-}$ : Murphy and Riley, 1962; $\mathrm{NH}_{4}{ }^{+}$: Aminot and Chaussepied, 1983; $\mathrm{Si}(\mathrm{OH})_{4}$ : Mullin and Riley, 1955). Water samples $(5 \mathrm{ml})$ for dissolved organic carbon (DOC) were kept in acid-washed vials and then filtered through GF/F. The filtrate was frozen at $-20^{\circ} \mathrm{C}$ until analysis. DOC concentrations were measured using a Shimadzu TOC-5000 carbon analyzer following the method of high-temperature catalytic combustion as described in the JGOFS report (Knap et al., 1994).

Chlorophyll a $(\mathrm{Chl} \mathrm{a)}$ concentrations were determined on $1000 \mathrm{ml}$ samples that were successively filtered through $10 \mu \mathrm{m}, 2 \mu \mathrm{m}$ and $0.2 \mu \mathrm{m}$ pore-size polycarbonate filters. Pigment concentrations were estimated, after overnight dark extraction at $4^{\circ} \mathrm{C}$ in $90 \%$ acetone, using the spectrophotometric method of Lorenzen (1976) and following the procedure given by Parsons et al. (1984).

Samples for identification and enumeration of phytoplankton $>2 \mu \mathrm{m}$ and microzooplankton were fixed with 4\% acid Lugol solution (Parsons et al., 1984) and 5\% alkaline Lugol solution (Sherr and Sherr, 1993), respectively. Cell abundances were determined under an inverted microscope (100 x objective) on 50-100 ml settled volumes (Lund et al., 1958). At least 200 cells in each sample were counted. Unfortunately, the smaller heterotrophic ultraflagellates $(<5 \mu \mathrm{m})$ were not quantified according to the DAPI method because of a technical problem. Lugol's is recognized to be a good fixative for ciliates since it preserves a great number of them (Leakey et al., 1994; Stoecker et al., 1995). Within this group, the species Mesodinium rubrum and Laboea strobila, which were regarded as mainly phototrophic, were included in the phytoplankton community. The preservation in acid Lugol's is problematic for dinoflagellates because it does not allow discrimination between the heterotrophic and autotrophic forms. Since the studies of Larsen and Sournia (1991) and Stoecker (1999) have shown that many, if not most, dinoflagellates are phagotrophic, species of Gymnodinium, Gyrodinium, Protoperidinium, Torodinium and Dinophysis were considered as heterotrophic in our results. However, Prorocentrum spp. were including within the algal community

To enumerate the picophytoplankton, samples $(10 \mathrm{ml})$ were preserved in $0.22 \mu \mathrm{m}$ prefiltered formaldehyde ( $2 \%$ final concentration) and stored for $1 \mathrm{~h}$ in darkness at $4^{\circ} \mathrm{C}$. The samples were then filtered on $0.22 \mu \mathrm{m}$ black polycarbonate filters (Nuclepore) laid over $0.45 \mu \mathrm{m}$ nitrocellulose backing filters (Millipore). The filters were mounted on slides using low-fluorescence immersion oil, and stored immediately at $-20^{\circ} \mathrm{C}$. Abundance was determined under a CETI Topic-T epifluorescence microscope (x100 Fluotar objective), as described in Maclsacc and Stockner (1993), using blue and green excitation and counting at least 200 cells from 30 random squares. 
Samples $(20 \mathrm{ml})$ for heterotrophic bacteria were preserved with glutaraldehyde (final concentration of $1 \%$ ), and stored in darkness at $4^{\circ} \mathrm{C}$. From each sample, $3 \mathrm{ml}$ were stained in the dark with $4^{\prime}, 6-$ diamidino-2-phenylindole (DAPI; $1.8 \mu \mathrm{g} \mathrm{I}^{-1}$ final concentration) (Porter and Feig, 1980) and filtered on $0.22 \mu \mathrm{m}$ black polycarbonate filters. The filters were mounted on slides and stored frozen until analysis. Bacterial enumeration was conducted with a 100x oil immersion objective under an Olympus $\mathrm{BH}-2$ epifluorescence microscope, using UV excitation. For each filter, 300 cells were counted from 20 random fields.

Samples for identification and enumeration of mesozooplankton were fixed in 5\% borax-buffered formalin solution. Count was performed under dissecting microscope (VOTPI Leica WILD M32).

\subsection{Dilution Experiments}

Dilution experiments (Landry and Hassett, 1982) were carried out on each station to estimate growth rates $\left(k, d^{-1}\right)$ of phytoplankton $\left(k_{\mathrm{Ph}}\right)$ and bacteria $\left(\mathrm{k}_{\mathrm{Bac}}\right)$ as well as rates of microzooplankton grazing $(\mathrm{g}$, $\left.\mathrm{d}^{-1}\right)$ on them ( $\mathrm{g}_{\mathrm{Ph}}$ and $\left.\mathrm{g}_{\mathrm{Bac}}\right)$. The description of the experiment procedure was detailed in Sakka Hlaili et al. (2007).

The data of $\mathrm{k}\left(\mathrm{k}_{\mathrm{Ph}}\right.$ or $\left.\mathrm{k}_{\mathrm{Bac}}\right)$ and $\mathrm{g}\left(\mathrm{g}_{\mathrm{Ph}}\right.$ or $\left.\mathrm{g}_{\mathrm{Bac}}\right)$, estimated from the dilution experiments, were then used to calculate the production $(P)$ and the consumption rates $(G)$ of phytoplankton ( $P_{\mathrm{Ph}}$ and $G_{\mathrm{Ph}}$ ) or of bacteria $\left(P_{\mathrm{Bac}}\right.$ and $\left.\mathrm{G}_{\mathrm{Bac}}\right)$ using the equation of Moigis (2000):

$\mathrm{P}\left(\mathrm{mg} \mathrm{C} \mathrm{m}{ }^{-3} \mathrm{~d}^{-1}\right)=\mathrm{k} \times[(\mathrm{k}-\mathrm{g}) \mathrm{t}]^{-1} \times \mathrm{B}_{0}\left[\mathrm{e}^{(\mathrm{k}-\mathrm{g}) \mathrm{t}}-1\right]$

$\mathrm{G}\left(\mathrm{mg} \mathrm{C} \mathrm{m} \mathrm{m}^{-3} \mathrm{~d}^{-1}\right)=\mathrm{g} \times[(\mathrm{k}-\mathrm{g}) \mathrm{t}]^{-1} \times \mathrm{B}_{0}\left[\mathrm{e}^{(\mathrm{k}-\mathrm{g}) \mathrm{t}}-1\right]$

Were $B_{0}\left(\mathrm{mg} \mathrm{C} \mathrm{m}^{-3}\right)$ is the initial biomass of phytoplankton or bacteria, and $t(d)$ is the incubation time $(1 \mathrm{~d})$.

\subsection{Estimation of carbon biomasses}

\subsubsection{Phytoplankton and protozooplankton}

The dimension of algal and protozoan taxa (at least 50 cells) were measured using a calibrated ocular micrometer and biovolumes were estimated by applying standard geometric formulae to each taxon, as proposed by Hillebrand et al. (1999). For diatoms, the vacuole volume was subtracted from the cell volume (Hillebrand et al., 1999), assuming a plasma layer thickness of $1 \mu \mathrm{m}$, and the $C$ content was obtained using the formula of pg C cell ${ }^{-1}=0.288 \times \mathrm{V}^{0.811}$ (Menden-Deuer and Lessard, 2000), where $\mathrm{V}$ is the cell volume. The cell volume $(\mathrm{Z})$ of autotrophic flagellates and dinoflagellates, was converted to cell carbon using the formula of pg C cell ${ }^{-1}=0.216 \times \mathrm{Z}^{0.939}$ (Menden-Deuer and Lessard, 2000). Cell carbon for ciliates and heterotrophic flagellates were computed with conversion factors of $0.19 \mathrm{pg}$

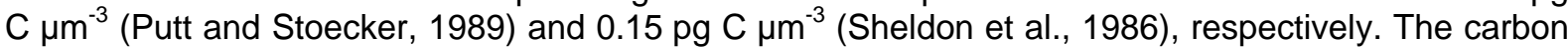
biomasses of phytoplankton and protozooplankton were estimated by multiplying their cell carbon by the abundances.

\subsubsection{Picophytoplankton and heterotrophic bacteria}

For picophytoplankton and heterotrophic bacteria, the biovolumes were calculated from the average cell dimension of 100 organisms in each group. Cell volumes $\left(\mu \mathrm{m}^{3}\right)$ were converted to cell carbon

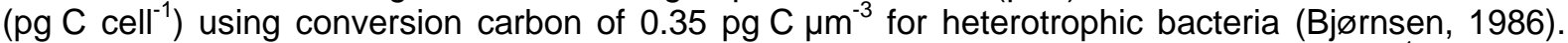
Their carbon biomasses were estimated by multiplying their cell carbon $\left(22.2 \mathrm{fg} \mathrm{C} \mathrm{cell}^{-1}\right)$ by their abundances. For picocyanobacteria and eukaryotic picophytoplankton, carbon biomasses were

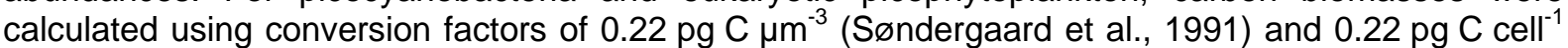
(Mullin et al., 1966), respectively.

\subsubsection{Mesozooplankton}

The length and width of all organisms in each sample were measured. These measurements were converted to biomass using conversion factors corresponding to each taxonomic group, as follows:

- Copepods: The total volume $(\mathrm{V}, \mathrm{nl})$ was calculated by applying geometric formulae of ellipsoid and cylinder to prosom and urosom, respectively. The wet weight $(\mathrm{WW}, \mu \mathrm{g})$ was calculated according to Riemann et al. (1990) as:

$\mathrm{WW}=0.9 \times \mathrm{V} \times 1.13$ 
where 0.9 is a dimensionless conversion factor, $\mathrm{V}(\mathrm{nl})$ is the total volume of a given individual and 1.13 is the specific gravity $\left(\mu \mathrm{g} \mathrm{nl}^{-1}\right)$. The dry weight (DW, $\mu \mathrm{g}$ ) was calculated as $22.5 \%$ of WW (Gradinger et al., 1999) and C content $(\mu \mathrm{g})$ was estimated as $40 \%$ of DW (Feller and Warwick, 1988).

- Copepod nauplii: Biovolumes were estimated by applying standard geometric formulae to each individual, and the $C$ content was obtained using a conversion factor of $0.50 \mathrm{pg}^{-3} \mathrm{~m}^{-3}$ (Shinada et al., 2003).

- Cladocera: The length $(\mathrm{L}, \mathrm{mm})$ of each organism was used the determined its carbon content $\left(\mathrm{C}_{\text {clad }}\right)$ as:

$\mathrm{C}_{\text {clad }}(\mu \mathrm{g})=5.24 \times \mathrm{L}-1.08$

- Bivalve larvae: The wet weight of an organism was calculated according to Jespersen and Olsen (1982) as:

WW $(\mu \mathrm{g})=2.53 \times 10^{-9} \times \mathrm{L}^{3.49}$

where $L(\mathrm{~mm})$ is the individual length. Larval carbon content was estimated by multiplying the WW by a factor of 0.22 (Omori, 1969).

- Other larvae: The individual settled volume $\left(\mathrm{SV}, \mathrm{cm}^{3}\right)$ was calculated by applying a specific geometric formula to each larva. The dry volume (DV, $\mathrm{cm}^{3}$ ) was estimated as $0.35 \times \mathrm{SV}$, and the carbon content was calculated considering that $0.1 \mathrm{~cm}^{3}$ of DV corresponds to $10 \mathrm{mg}$ of $C$ (Harris et al., 2000).

The carbon biomass of each metazoan group was estimated by multiplying the individual carbon contents by the corresponding abundances.

\subsection{Statistical analyses}

Analyses were performed using XLSTAT @ for Windows. A one-way analysis of variance (ANOVA) was performed to test the significance of differences in abiotic and biotic variables among stations and depths. The ANOVA was followed by a pair-wise multiple comparison test (Student-Newman-Keuls method) to identify which groups were significantly different from the others. When the normality of distribution (test of Kolmogorov-Smirnov) and/or the homogeneity of variances (test of Bartlett-Box) were failed, a non-parametric test (Kruskal-Wallis one way ANOVA on ranks) was used.

\section{Results}

\subsection{Environmental conditions}

Table 2 summarises physico-chemical and $\mathrm{Chl}$ a data recorded during the field. Salinity, water temperature, $\mathrm{NO}_{2}{ }^{-}, \mathrm{PO}_{4}{ }^{3-}$ and $\mathrm{DOC}$ concentrations exhibited no significant differences $(\mathrm{P}>0.05)$ among stations and depths (Table 3 ). $\mathrm{NO}_{3}{ }^{-}, \mathrm{Si}(\mathrm{OH})_{4}$ and $\mathrm{Chl}$ a concentrations were not significantly different over depths in each station, but exhibited horizontal spatial heterogeneity (Table 3). Higher concentrations of $\mathrm{NO}_{3}{ }^{-}(3.38-5.30 \mu \mathrm{M})$ and $\mathrm{Si}(\mathrm{OH})_{4}(11.71-13.30 \mu \mathrm{M})$ were recorded at station $\mathrm{MJ}$. $\mathrm{Chl}$ a levels recorded at station MB (1.93-2.94 $\left.\mathrm{g} \mathrm{I}^{-1}\right)$ were significantly lower than values measured at the other stations (3.10-5.48 $\mu \mathrm{g} \mathrm{I}{ }^{-1}$ ) (Table 3). In most stations, $\mathrm{NH}_{4}{ }^{+}$decreased significantly with depth and highest concentrations were recorded at surface water of station MJ (14.21 $\mu \mathrm{M})$ and MA $(13.71 \mu \mathrm{M})$.

\subsection{Trophic group biomasses}

The carbon biomasses of most trophic groups exhibited only significant horizontal spatial variations (Table 3). For all stations, vertical profiles of the heterotrophic bacteria and picophytoplankton were homogenous (Table 3, Fig. 2A, B). For both groups, highest levels were estimated at station MJ (bacteria: $26.4-33.5 \mathrm{mg} \mathrm{C} \mathrm{m}^{-3}$, picophytoplankton: $17.4-18.9 \mathrm{mg} \mathrm{C} \mathrm{m}^{-3}$ ). The lowest concentrations were recorded at stations $\mathrm{R}$ for bacteria $\left(6.7-9.5 \mathrm{mg} \mathrm{C} \mathrm{m}^{-3}\right)$ and at station $\mathrm{MB}$ for picophytoplankton $\left(4.5-6.4 \mathrm{mg} \mathrm{C} \mathrm{m}^{-3}\right)$. Nanophytoplankton biomasses $\left(6.2-19.2 \mathrm{mg} \mathrm{C} \mathrm{m}^{-3}\right)$, which were almost unchanged among stations, decreased from subsurface waters to depth (Table 3, Fig. 2C). Microphytoplankton biomasses exhibited horizontal spatial heterogeneity (Table 3 ). The Highest and lowest biomasses were observed at stations MJ $\left(222.5-260.4 \mathrm{mg} \mathrm{C} \mathrm{m}^{-3}\right)$ and $\mathrm{R}(65.8$ $101.6 \mathrm{~g} \mathrm{C} \mathrm{m}^{-3}$ ), respectively (Fig. 2D). Microzooplankton biomasses, which were invariable with depth, were similar among stations MA, MJ and R (135 - $\left.205 \mathrm{mg} \mathrm{C} \mathrm{m}^{-3}\right)$. Levels at station MB (343 $357 \mathrm{mg} \mathrm{C} \mathrm{m}^{-3}$ ) largely exceeded that of the other stations (Fig. 2E). Mesozooplankton exhibited higher biomasses at stations MA $\left(7.54 \mathrm{mg} \mathrm{C} \mathrm{m}^{-3}\right)$ and $\mathrm{MJ}\left(7.58 \mathrm{mg} \mathrm{C} \mathrm{m}^{-3}\right)$ than at stations R $\left(5.03 \mathrm{mg} \mathrm{C} \mathrm{m}^{-3}\right)$ 
and $\mathrm{MB}\left(2.25 \mathrm{mg} \mathrm{C} \mathrm{m}^{-3}\right.$ ). No depths comparison was done for mesozooplankton since these organisms were sampled by the mean of a tow through one surface layer.

\subsection{Taxonomic composition of trophic groups}

Taxonomic composition of $>2 \mu \mathrm{m}$ phytoplankton (nano- and microphytoplankton) was illustrated in Fig. 3. During our study period, diatoms were remarkably abundant at different depths for all stations, contributing $63-89 \%$ of the total algal biomass. The highest diatom biomass was recorded at station MJ (204 - $231 \mathrm{mg} \mathrm{C} \mathrm{m}^{-3}$ ). In stations MA and MJ, diatoms were dominated by pennate species (Bidulphia sp., Entomoneis pellucida, Gyrosigma spp., Licmophora gracilis, Pleurosigma strigosum, Nitzschia spp., Pseudo-nitzschia spp., Melosira sp., Navicula sp. and Thalassionema spp.), while centric cells (Chaetoceros spp., Cerataulina spp., Skeletonema costatum, Coccinodiscus sp., Dactyliosolen fragilissimus, Guinardia spp., Rhizosolenia imbricata and Thalassiosira spp.) were prevailing in stations $M B$ and R. Autotrophic dinoflagellates, which were represented by several species of Prorocentrum, accounted for $7-21 \%$ of total phytoplankton biomass at the four stations. The photosynthetic ciliates Mesodinium rubrum and Laboea strobila were present at stations MA, MB and $\mathrm{R}$, contributing $1-5 \%$ of algal biomass. In station MJ, Mesodinium rubrum was the only species observed within the autotrophic ciliate community, which accounted for $0.3 \%$ of algal biomass. Chlorophyceae (Chlamydomonas spp.), cryptophyceae (Hillea and Plagioselmis spp.), prasinophyceae (Pyramimonas, Tetraselmis and Mamiella spp.) and unidentified flagellates (due to their small size, generally $<5 \mu \mathrm{m}$ ) constituted $2.5-10.5 \%$ of algal biomass.

At different depths for all study stations, the microzooplankton were dominated by heterotrophic dinoflagellates and ciliates which contributed $26-53 \%$ and $44-70 \%$ of total biomass, respectively (Fig. 4). Dinoflagellates were mostly dominated by Torodinium, Protoperidinium and Dinophysis spp. Tintinnids (Tintinnopsis, Tintinnus, Favella and Eutintinnus spp.) were mostly abundant at station MB, while aloricate organisms (Lohmaniellea and Stombidium spp.) were the dominant ciliates in other stations. Heterotrophic flagellates, which contributed of $1.5-13.5 \%$ of microzooplankton biomass, were dominated by small $(<10 \mu \mathrm{m})$ species of Leucocryptos and Teleaulax and large organisms $(>10 \mu \mathrm{m})$ of Dictyocha and Ebria. Within this group the heterotrophic ultraflagellates $(<5 \mu \mathrm{m})$ were not enumerated and hence their biomass may be underestimated. But, due to their small cell size, the ultraflagellates would contribute weakly to the carbon biomass of microzooplankton.

Within the mesozooplankton community (Fig. 5), copepods, the dominant group (50-90\% of total abundance), were represented by calanoida (Acartia, Temora, Calanus, Eucalanus, Paracalanus and Centropages) and cyclopoida (Oithona). Cladocera (Pondon) were observed only at station MB representing $2 \%$ of total metazoan abundance. The large dinoflagellate Noctiluca represented $3 \%$ of the metazoan abundance in station MA. Copepod nauplii and larvae of several groups (medusa, annelids, mussels, gasteropods, fish, appendicularians, decapods, echinoderma, acisidiacea and tubellaria) were also observed at different stations.

\subsection{Bacterial and phytoplankton production and grazing}

Bacterial and phytoplankton size-classes production and grazing rates are summarised in Table 4. Overall, these rates exhibited more variations among stations than among depths (Table 3 ).

The highest bacterial production rates were observed at station MJ $\left(27.5\right.$ to $\left.34.8 \mathrm{mg} \mathrm{C} \mathrm{m}^{-3} \mathrm{~d}^{-1}\right)$. Similar values $\left(17.5-24.5 \mathrm{mg} \mathrm{C} \mathrm{m}^{-3} \mathrm{~d}^{-1}\right)$ were found at stations MA, MB and R. Picophytoplankton production at station MJ $\left(6.3-6.8 \mathrm{mg} \mathrm{C} \mathrm{m}^{-3} \mathrm{~d}^{-1}\right)$ were also higher than those observed at stations MA, MB and R $\left(1.97-3.24 \mathrm{mg} \mathrm{C} \mathrm{m}^{-3} \mathrm{~d}^{-1}\right)$. Production rates for nanophytoplankton $\left(2.7-11.5 \mathrm{mg} \mathrm{C} \mathrm{m}^{-3} \mathrm{~d}^{-1}\right)$, which were similar among stations, decreased with depth. Microalgae had high production rates at station MJ $\left(163.9\right.$ - $\left.191.6 \mathrm{mg} \mathrm{C} \mathrm{m}^{-3} \mathrm{~d}^{-1}\right)$. Lower values were measured at station MA (74.4 $\left.91.6 \mathrm{mg} \mathrm{C} \mathrm{m}^{-3} \mathrm{~d}^{-1}\right)$ and the lowest were recorded at stations MB and $\mathrm{R}\left(28.9-52.3 \mathrm{mg} \mathrm{C} \mathrm{m}^{-3} \mathrm{~d}^{-1}\right)$.

Grazing on bacteria amounted to $17-27.7 \mathrm{mg} \mathrm{C} \mathrm{m}^{-3} \mathrm{~d}^{-1}$ at station $\mathrm{MJ}$, and lower values (5.8 $13 \mathrm{mg} \mathrm{C} \mathrm{m}^{-3} \mathrm{~d}^{-1}$ ) were recorded in the others stations. Levels of grazing were equivalent to daily losses of $56-78 \%$ of bacterial production in stations MA and MJ and $33-38 \%$ in stations MB and R. Grazing rates for pico- and microphytoplankton measured at station $\mathrm{MJ}$ (picophytoplankton: 3.5 $5.0 \mathrm{mg} \mathrm{C} \mathrm{m}^{-3} \mathrm{~d}^{-1}$, microphytoplankton: $57.7-87.9 \mathrm{mg} \mathrm{C} \mathrm{m}^{-3} \mathrm{~d}^{-1}$ ) distinctly exceeded those recorded in the other stations (picophytoplankton: $1-3 \mathrm{mg} \mathrm{C} \mathrm{m}^{-3} \mathrm{~d}^{-1}$, microphytoplankton: 16.3 $\left.37.2 \mathrm{mg} \mathrm{C} \mathrm{m}^{-3} \mathrm{~d}^{-1}\right)$. Grazing rates for nanophytoplankton $\left(1.4-7.6 \mathrm{mg} \mathrm{C} \mathrm{m}^{-3} \mathrm{~d}^{-1}\right)$ exhibited no significant differences among stations but decreased with depth (Table 3). The microzooplankton 
grazing corresponded to daily losses of $50-92 \%$ of the pico- and nanophytoplankton production in the four stations. In all stations, the micro-consumers daily grazed $34-49 \%$ of the microalgal production.

\section{Discussion}

\subsection{Eutrophic status of the lagoon}

As reported for many others coastal systems (Souissi et al., 2000), horizontal spatial heterogeneity in the Bizerte lagoon appeared to be a more important source of variation in abiotic and biotic variables than the vertical one (Table 3 ).

Nutrient concentrations are frequently used as water quality indicators because they represent the chemical factors that are influenced by human activities (Stumm and Baccini, 1983). The station MJ located in shellfish farming sector exhibited higher concentrations of $\mathrm{NO}_{3}{ }^{-}$than the others stations (Tables 2, 3). The $\mathrm{Si}(\mathrm{OH})_{4}$ was another factor for the horizontal spatial dissimilarity (Table 3). According to the sediment granulometry, the centre of the lagoon was mainly composed by silts, while sands are dominant in west (45\%) and east (90\%) sectors (Harzallah, 2003). Thereby, the increased $\mathrm{Si}(\mathrm{OH})_{4}$ concentrations in the station $\mathrm{MJ}$ (situated in East of the lagoon) may be related to the sediment characteristics of the station.

The lagoon is characterized by relatively high concentrations of inorganic nitrogen and phosphorous as shown in this study $\left(\mathrm{NO}_{2}^{-}+\mathrm{NO}_{3}^{-}+\mathrm{NH}_{4}^{+}: 2.84-17.9 \mathrm{N \mu M} ; \mathrm{PO}_{4}{ }^{3+}: 0.13-1.62 \mathrm{P} \mu \mathrm{M}\right)$ and in previous investigations (Sakka Hlaili et al., 2006; Sakka Hlaili et al., 2007). These nutrient levels compared to those reported for other Mediterranean coastal systems, as lagoon of Thau $(10.7 \mathrm{~N} \mu \mathrm{M}$, 1.3 P $\mu \mathrm{M}$; Vaquer et al., 1996) and gulf of Trieste $(0.44-11.1 \mathrm{~N} \mu \mathrm{M}, 0.1-1.02 \mathrm{P} \mu \mathrm{M}$; Fonda Umani and Beran, 2003). Chl a concentrations measured during summer in our study site $\left(1.93-5.48 \mu \mathrm{g} \mathrm{I}^{-1}\right)$ were also in the range of levels reported for the two coastal ecosystems (Thau lagoon: $0.40-$ $5.38 \mu \mathrm{gl}^{-1}$, Bec et al., 2005; gulf of Trieste: $0.40-5.90 \mu \mathrm{g} \mathrm{I}^{-1}$ Fonda Umani and Beran, 2003) but exceeded those reported in open-sea waters of Mediterranean, as the Aegean Sea $\left(0.04-0.10 \mu \mathrm{g} \mathrm{I}^{-1}\right.$, Robinson, 2000), the Catalano-Balearic Sea $\left(0.16-1.29 \mu \mathrm{g} \mathrm{I}^{-1}\right.$, Pedrós-Alió et al., 1999) and the Algerian basin $\left(0.2-1.2 \mu \mathrm{gl}^{-1}\right.$, Morán et al., 2001). Chl a levels encountered in the Bizerte Lagoon were low when compared with those measured in the eutrophicated Orbetello lagoon (until $66 \mu \mathrm{g} \mathrm{I}^{-1}$ ), in which total N-nutrient levels can reached $70 \mu \mathrm{M}$ (Nuccio et al., 2003). Considering its nutrients and $\mathrm{Chl}$ a status, the Bizerte lagoon can therefore be classified in the lower range of eutrophicated systems. However, the enclosed nature of the lagoon and the long renewal time of water (several months, Harzallah, 2003) can accentuate its eutrophication state in the future.

\subsection{Bacterial assemblage}

Biomasses of heterotrophic bacteria $\left(7-33 \mathrm{mg} \mathrm{C} \mathrm{m}^{-3}\right.$ or $3-1510^{8}$ cells $\left.\mathrm{I}^{-1}\right)$ varied significantly among stations (Table 3) with higher values at station MJ (Fig. 2A). The bacterial concentrations were in the range of values reported for a coastal site in the Northern Adriatic Sea (22-27 $\mathrm{mg} \mathrm{C} \mathrm{m}^{-3}$, Fonda Umani et al., 2005), but higher than those found for oligotrophic open-sea waters in the NW and E Mediterranean $\left(\leq 510^{8}\right.$ cells $\left.\right|^{-1}$ and $\leq 9 \mathrm{mg} \mathrm{C} \mathrm{m}^{-3}$, Gasol et al., 1998; Pedrós-Alió et al., 1999).

Bacterial production rate exhibited also spatial horizontal variation and varied from 17.5 to $35 \mathrm{mg} \mathrm{C} \mathrm{m}^{-3} \mathrm{~d}^{-1}$ (Tables 3,4). These rates, measured during summer, were higher than values reported for open-sea waters of the northern, eastern and southern Mediterranean $\left(<5 \mathrm{mg} \mathrm{C} \mathrm{m}^{-3} \mathrm{~d}^{-1}\right.$, Fernández et al., 1994; Pedrós Alió et al., 1999; Morán et al., 2001), but similar to level measured in the gulf of Triest, North Adriatic Sea $\left(46 \mathrm{mg} \mathrm{C} \mathrm{m}^{-3} \mathrm{~d}^{-1}\right.$. Fonda Umani and Beran, 2003). During the study, higher rates of bacterial production were found in the station MJ (Table 4). The significant algal production in this station (Table 4) may contribute to a substantial exudation of labile DOC that can be readily taken by bacteria, thus, enhancing their growth rates. Over all stations, bacteria seemed to be able to process a significant fraction of carbon fixed by phytoplankton. Indeed, the ratio of bacterial production to phytoplankton production ranged from 0.2 to 0.5 , which is not so different from the value 0.3 reported at a global scale (Cole et al., 1988).

\subsection{Phytoplankton assemblage}

The microphytoplankton remarkably dominated the algal carbon biomass (>82\%, Fig. 2D) and production (84 - 92\%, Table 4) in all stations during summer, a season characterized by the 
proliferation of several chain-forming diatoms (Fig. 3). The summer abundance of diatoms is likely a common feature of several Mediterranean coastal systems like the lagoon of Mar Menor (Spanish coast, Gilabert, 2001), the Bay of Tunis (Tunisian coast, Daly Yahia-Kéfi et al., 2005) and the Orbetello lagoon (Italian coast, Nuccio et al., 2003). The significant contribution of diatoms to phytoplankton may be related to the high nutrient levels measured in the lagoon during summer (Sakka Hlaili et al., 2006), which could favour the growth of large algae. Indeed, over all stations, growth rates of microalgae $\left(0.41-0.63 \mathrm{~d}^{-1}\right)$ were higher than those of nano- $\left(0.31-0.50 \mathrm{~d}^{-1}\right)$ and picophytoplankton $\left(0.21-0.41 \mathrm{~d}^{-1}\right)$ (Sakka Hlaili et al., 2007). Moreover, the increased availability of Si in station MJ, may lie behind the substantial biomass of diatoms (Fig. 2D) and the significant production of microphytoplankton (Table 4) in this station. According to the phytoplankton production levels, measured during summer in the lagoon $\left(34-210 \mathrm{mg} \mathrm{C} \mathrm{m}^{-3} \mathrm{~d}^{-1}\right.$ or $440-1779 \mathrm{mg} \mathrm{C} \mathrm{m}^{-2} \mathrm{~d}^{-1}$ ), our study site can be considered as a moderate to highly productive system, which compares to other Mediterranean lagoons as Thau $\left(4-576 \mathrm{mg} \mathrm{C} \mathrm{m}^{-3} \mathrm{~d}^{-1}\right.$, Bec et al., 2005) and Venice (2.7 $2740 \mathrm{mg} \mathrm{C} \mathrm{m}^{-2} \mathrm{~d}^{-1}$, Flindt et al., 1997).

The picophytoplankton concentrations (5.4- $18.4 \mathrm{mg} \mathrm{C} \mathrm{m}^{-3}$ or $2.4-8.410^{7}$ cells I $\mathrm{I}^{-1}$ ) varied significantly among stations (Table 3) with higher values at station MJ (Fig. 2B). The cell number of picoalgae measured in the lagoon fell in the range of values reported for several Mediterranean zones (Vaulot et al., 1990; Magazzù and Decembrini, 1995; Morán et al., 2001). When compared to nano- and microphytoplankton, picocells were more numerous in the studied lagoon, as observed in the Thau lagoon (Vaquer et al., 1996; Bec et al., 2005), but due to their low mean volume per cell $\left(0.99 \mathrm{\mu m}^{3}\right)$ and low C:Chl a ratio (6, average value over all stations and depths), the picophytoplankton contributed weakly to the carbon biomass of phytoplankton during summer in all stations. However, the contribution of $<2 \mu \mathrm{m}$ cells to total $\mathrm{Chl}$ a was on average (for all stations and depths) $49 \%$, slightly lower than the mean percent (59\%) reported for several Mediterranean areas (Magazzù and Decembrini, 1995). In all stations, picophytoplankton contributed $<6 \%$ to the primary production, which is largely lower than mean values given for pelagic (71\%) and neritic (44\%) Mediterranean areas (Magazzù and Decembrini, 1995). However, the contribution of $<2 \mu \mathrm{m}$ cells to phytoplankton production, in the Thau lagoon, was reported to be lower than the large algae (Bec et al., 2005). In general, photosynthetic activity of picoalgae was reported to be higher than that of large cells (De Madariaga and Joint, 1994), which may be related to the physiologic advantage of $<2 \mu \mathrm{m}$ cells (i.e. high efficiency of nutrient uptake). This hypothesis may be considered under nutrient-deficient conditions and in oligotrophic areas. However, in eutrophic ecosystems and during large cells proliferation events, the picophytoplankton activity may be lower and hence their contribution to primary production would be low.

\subsection{Zooplankton assemblages}

During summer, microzooplankton was dominated by heterotrophic dinoflagellates and ciliates (Fig. 4) and exhibited high concentrations (310-981 x 10 cells ${ }^{-1}$, or $135-357 \mathrm{mg} \mathrm{C} \mathrm{m}^{-3}$ ), which exceed values found in other open-sea and coastal areas of the Mediterranean Sea (Lam-Hoai and Rougier, 2001; Gómez and Gorsky, 2003; Fonda Umani et al., 2005). It is suggested that microzooplankton would be significant grazers in the lagoon and thus microbial food webs would be active, if mesograzers are not more important. Microzooplankton biomass exhibited spatial horizontal variation (Table 3) with very higher values at station MB (Figs. 2E, 4). This station was characterized by lower abundance of copepods (Fig. 5), the potential predators of ciliates and heterotrophic dinoflagellates (Jürgens et al., 1999; Calbet and Saiz, 2005). It is suggested that lower copepod predation on micrograzers may account to the high protozoan concentration in the station MB.

In most stations, mesozooplankton communities observed during summer were quantitatively dominated by copepods (50 - 90\% of total number, Fig. 5), as reported in other Mediterranean regions (Christaki et al., 1998; Fonda Umani et al., 2005). Biomasses of mesozooplankton estimated in the lagoon $\left(2.2-7.6 \mathrm{mg} \mathrm{C} \mathrm{m}^{-3}\right)$ were similar to those found in other coastal Mediterranean systems, as lagoon of Thau (NW Mediterranean, Lam-Hoai and Rougier, 2001) and gulfs of Triest (N Adriatic Sea, Fonda Umani et al., 2005) and of Patraikos (Ionian Sea, Ramfos et al., 2006). The mesozooplankton contributed to the horizontal spatial variations (Table 3) with pronounced biomasses at stations MJ, which were characterized by high biomass and production of microalgae such as diatoms (Table 4 , Fig. 2D). It is suggested that the herbivorous food web would be active in this station as diatoms production could be directly or indirectly (via microzooplankton grazing) channelled to metazoan zooplankton contributing to an important carbon flow to higher tropic levels. 


\subsection{Zooplankton grazing}

Microzooplankton grazing on bacteria varied among stations (Table 3 ). Rates observed at station MJ (17-27 mg C m $\mathrm{m}^{-3}$ ) were higher than values at the others stations $\left(6-13 \mathrm{mg} \mathrm{C} \mathrm{m}^{-3} \mathrm{~d}^{-1}\right.$ ) (Table 4). A higher fraction of bacterial production was removed at stations MJ and MA (mean over depths: 65 $70 \%$ ) in comparison with stations MB and R (mean over depths: $35 \%$ ). Obviously, small heterotrophic flagellates can contributed to the high bacterivory in stations MA and $\mathrm{MJ}$, but also ciliates may be active bacterivorous, as small aloricate organisms (Strombidium spp.) represented $95-100 \%$ of ciliate abundance and biomass in both stations (Fig. 4).

Over all stations, the pico- and nanophytoplankton were efficiently consumed by microzooplankton during summer, since large fractions of their production (picoalgae: $51-96 \%$, nanoalgae: $51-91 \%$, Table 4) were daily removed. The small heterotrophic flagellates and aloricate ciliates, observed in the lagoon, may also control the production of the small producers, as reported in other aquatic systems (Šimek et al., 1995; Sakka et al., 2000). Large ciliates (i.e. tintinnids) may indirectly control the small algae, by ingesting their potential consumers, the heterotrophic flagellates. This can be significant particularly in station MB, where high biomass of large tintinnids ( $>130 \mu \mathrm{m}$, Eutintinnus and Favella) was found (Fig. 4). In comparison to ciliates, heterotrophic dinoflagellates are generally capable to graze larger cells (Bernard and Rassoulzadegan, 1990; Hansen, 1992). In the lagoon, heterotrophic dinoflagellates can indirectly influence bacteria as well as small algae, via their predation on small ciliates and/or heterotrophic flagellates (Lessard and Swift, 1985; Strom and Morello, 1998).

Pico- and nanocells are suitable preys for microzooplankton but microalgae (i.e. diatoms) were also shown to constitute another source of carbon to the microconsumers in several coastal systems (Böttjer and Morales, 2005, Stelfox-Widdicombe et al., 2004). Furthermore, ciliates and heterotrophic dinoflagellates, including Gyrodinium and Protoperidinium, are potential grazers of large algae such as chain-forming diatoms and are often associated with diatom blooms (Sime-Ngando et al., 1995; Hansen and Calado, 1999; Stelfox-Widdicombe et al., 2004). During our study, heterotrophic dinoflagellates, which were numerous $(60-82 \%$ and $40-52 \%$ of microzooplankton abundance and biomass, respectively) and large ciliates (i.e. tintinnids), which were very abundant at station MB (Fig. 4), can also act as major grazers on large algae, at least at station MB. However, the microzooplankton removed a small fraction of the daily production of microphytoplankton in all stations (mean over depths, MA: 39\%, MB: 45\%, MJ: 40\%, R: 44\%, Table 4). This implies that a relatively important fraction of large algal production $(55-61 \%)$ would be controlled by other mechanisms, such as predation by planktonic and benthic metazoans or vertical sinking (Froneman et al., 1996; Murrell and Hollibaugh, 1998). During summer, the metazooplankton in the lagoon were dominated by calanoid and cyclopoid copepods which were recognized to be important grazers of large algae (Sommer et al., 2000). It is suggested that a large fraction of diatom production (60\%) would be processed by active herbivorous consumers in the station $\mathrm{MJ}$, characterized by very high copepod abundance (Fig. 5). In contrast, copepods were the less numerous at station MB (Fig. 5) and the high concentrations of dinoflagellates and ciliates in this station have been attributed to a low predation by copepods. This suggests that most of diatom carbon would sink in this station. In the two others stations (MA and R), both mechanisms (copepod transfer and vertical sinking) would act together in controlling of large algal production.

\subsection{Trophic interactions within the food webs in the different stations}

Our study simultaneously investigated production and consumption of the different planktonic elements (bacteria, pico-, nano- and microphytoplankton) and provides a picture of predatory interactions in the planktonic food webs of the studied stations during summer (Fig. 6). Carbon production rates of microzooplankton groups (heterotrophic dinoflagellates, ciliates and flagellates) were obtained by multiplying their specific growth rates (obtained from dilution experiments) and their respective biomasses. Then, their carbon demands can be estimated assuming a $30 \%$ growth efficiency (Straile, 1997).

In stations MA and MJ (Fig. $6 \mathrm{~A}$ and B), a significant fraction of bacterial production enters the planktonic food web and can reach metazoan because of the high bacterivory of protozooplankton (65-70\% of bacterial production). The bacterivorous grazers in both stations (small aloricate ciliates and heterotrophic flagellates) exhibited relatively high carbon demands $\left(31-40 \mathrm{mg} \mathrm{C} \mathrm{m}^{-3} \mathrm{~d}^{-1}\right)$. These micrograzers, exert also high grazing pressure on pico- and nanoalgae corresponding to carbon loss of $68-78 \%$ of the small algal production. Small aloricate ciliates and heterotrophic flagellates can themselves be consumed by heterotrophic dinoflagellates. Total production of these small protozoa (10 and $12 \mathrm{mg} \mathrm{C} \mathrm{m}^{-3} \mathrm{~d}^{-1}$, at stations MA and MJ, respectively) can supply $23-34 \%$ of the carbon requirement of dinoflagellates (29 and $52 \mathrm{mg} \mathrm{C} \mathrm{m}^{-3} \mathrm{~d}^{-1}$, at stations MA and MJ, respectively). The rest 
could come from the predation of dinoflagellates upon microalgae ( $\leq 32$ and $<71 \mathrm{mg} \mathrm{C} \mathrm{m}^{-3} \mathrm{~d}^{-1}$, at stations MA and MJ, respectively). In station MA, tintinnids can also contribute to the consumption of microphytoplankton. However, only a small fraction of microalgal production (39-40\%) was removed by microzooplankton. As discussed, in station $\mathrm{MJ}$, the most of microalgal production can be consumed by the numerous copepods and then efficiently transferred to higher pelagic and/or benthic consumers. In station MA, the main producers (i.e. microalgae) can be channelled to metazoans and/or sink. In both stations, metazoans can also prey on heterotrophic dinoflagellates and tintinnids, which graze on active bacterivorous and microbial consumers.

In stations $\mathrm{MB}$ and $\mathrm{R}$ (Fig. 6C, D), small microzooplankton (aloricate ciliates and heterotrophic flagellates) exhibited low bacterivory (35\% of bacterial production), while their predation on small algae was significant (67-90\% of pico- and nanoalgal production). Heterotrophic dinoflagellates and tintinnids probably ingest total production of the small micrograzers ( 8 and $6 \mathrm{mg} \mathrm{C} \mathrm{m}^{-3} \mathrm{~d}^{-1}$, at stations $\mathrm{MB}$ and $\mathrm{R}$, respectively) with the microalgal contribution to complete their carbon diet (35 and $25 \mathrm{mg} \mathrm{C} \mathrm{m}^{-3} \mathrm{~d}^{-1}$, at stations $\mathrm{MB}$ and $\mathrm{R}$, respectively). However, the herbivory on large algae was low (44-45\% of microalgal production). Metazoans may contribute to the microphytoplankton consumption, but since the copepods were not abundant, particularly in station MB, a large fraction of microalgal production would sink to depth.

The picture of the trophic interactions at stations MA and MJ observed during summer showed that microbial and herbivorous activities act together in channelling the biogenic carbon. This trophic pathway, which corresponds to a multivorous food web (Legendre and Rassoulzadegan, 1995), can then contribute to an efficient carbon transfer to higher trophic levels in both stations. Conversely, in stations $\mathrm{MB}$ and $\mathrm{R}$, biogenic carbon can reach higher consumers mainly via the significant microzooplankton grazing on microbes. This trophic pathway, which corresponds to a microbial food web (Rassoulzadegan, 1993), seemed to be inefficient in carbon transfer, since small cells were not the main producers during summer in the lagoon and thus the bulk of algal production would sink.

The picture of food webs found in summer at different stations may change during others periods since seasonal changes in algal community were previously reported in the lagoon (Sakka Hlaili et al., 2006, 2007). Diatoms are abundant in spring and summer but small autotrophic flagellates prevailed in winter and autumn. During these seasons, small algae contributed $>85 \%$ of algal carbon biomass and the $<10 \mu \mathrm{m}$ phytoplankton accounted for $>70 \%$ of the total primary production (Sakka Hlaili et al., 2007). It is suggested that the production of the small producers would be mainly channelled to higher consumers by microbial food webs during winter and autumn.

\section{Conclusion}

This study provides the first information on trophic interactions involving bacteria, small and large phytoplankton and microzooplankton (heterotrophic flagellates, ciliates and dinoflgaellates) during summer in the Bizerte lagoon. Our results indicate that there are two different planktonic food webs: the multivorous food web in the north sector of the lagoon (stations MA and $\mathrm{MJ}$ ) and the microbial food web in the south sector (stations MB and R). The distinction between the two sectors may be related to the difference in the anthropogenic activities that were supported by different areas of the lagoon. In the North, there are three main cities (Bizerte, Menzel Abderrahman and Menzel Jemil with 100000 , 10000 and 25000 local peoples, respectively), while Menzel Bourguiba (with 25000 local peoples) is the only principal city located in the South (Fig. 1). According to the report of the ANPE (Agence Nationale de la Protection de l'Environnement, 1998), the waste water discharge in the lagoon was estimated at $120 \mathrm{Id}^{-1}$ people ${ }^{-1}$, which indicates that the urban loading of material would be more important in the North than in the South. Moreover, the northern sector of the lagoon supports several shellfish farming, while there is no conchylicous activity in the southern region (Fig. 1). It is suggested that high anthropogenic loading of nutrients may occur in the North and then may sustain the multivorous food web in the northern region of the lagoon

\section{Acknowledgements}

The present study was supported by grants from the Agence Universitaire de la Francophonie (AUF) to A. S. H., N. N. and M. G. and from the Natural Sciences and Engineering Research Council (NSERC) of Canada to M. G. Experiments performed during this study complied with the current laws 
of Tunisia. We thank anonymous reviewers for useful suggestions. This is a contribution to the research programs of ISMER and Québec-Océan.

\section{References}

Aminot, A. and Chaussepied, M., 1983. Manuel des analyses chimiques en milieu marin. Centre National pour l'Exploitation des Océans, Brest, 395 pp.

ANPE. 1998. Diagnostic préliminaire pour l'étude de l'équilibre écologique du lac de Bizerte. $72 \mathrm{pp}$.

Azam, F., Fenchel, T., Field, J.G., Gray, J.G., Meyer-Reil, L.A., Thingstad, F., 1983. The ecological role of water column microbes in the sea. Marine Ecology Progress Series 10, 257-263.

Bec, B., Husseini-Ratrema, J., Collos, Y., Souchu, P., Vaquer, A., 2005. Phytoplankton seasonal dynamics in a Mediterranean coastal lagoon: emphasis on the picoeukaryote community. Journal of Plankton Research 27, 881-894.

Bernard, C., Rassoulzadegan, F., 1990. Bacteria or microflagellates as a major food source of marine ciliates: possible implications for the microzooplankton. Marine Ecology Progress Series 64, 147-155.

Bjørnsen, P.K., 1986. Automatic determination of bacterioplankton biomass by image analysis. Applied Environmental Microbiology 51, 1199-1204.

Böttjer, D., Morales, C.E., 2005. Microzooplankton grazing in a coastal embayment off Concepción, Chile, $\left(36^{\circ} \mathrm{S}\right)$ during non-upwelling conditions. Journal of Plankton Research 27, 383-391.

Bouvy, M., Pagano, M., M'Boup, M., Got, P., Troussellier, M., 2006. Functional structure of microbial food web in the Senegal River Estuary (West Africa): impact of metazooplankton. Journal of Plankton Research 28, 195-207.

Calbet, A., Landry, M.R., 1999. Mesozooplankton influences on the microbial food web: direct and indirect trophic interactions in the oligotrophic open ocean. Limnology and Oceanography 44, 13701380.

Calbet, A., Landry, M.R., Nunnery, S., 2001. Bacteria-flagellate interactions in the microbial food web of the oligotrophic subtropical North Pacific. Aquatic Microbial Ecology 23, 283-292.

Calbet, A., Saiz, E., 2005. The ciliate-copepod link in marine ecosystems. Aquatic Microbial Ecology 38, 157-167.

Christaki, U., Gaudy, R., Kerambrun, P., 1998. A study of the effects of migratory zooplankton on microbial populations in surface waters of the N.W. Mediterranean. Journal of Experimental Marine Biology and Ecology 225, 173-183.

Cole, J.J., Findlay, S., Pace, M.L., 1988. Bacterial production in fresh and saltwater ecosystems: a cross-system overview. Marine Ecology Progress Series 43, 1-10.

Daly-Yahia, M.N., Daly Yahia-Kéfi, O., Souissi, S., Maamouri, F., Aissa, P., 2005. Associations Tintinnids (Ciliophora, Tintinnina)-Dinoflagellés (Dinophyceae) autotrophes potentiellement nuisibles au niveau de la Baie de Tunis et de deux lagunes associées: Ghar El Melh et Tunis Sud (Méditerranée Sud Occidentale). La Mer 43, 19-32.

Daly-Yahia Kéfi, O., Soussi, S., Gomez, F., Daly Yahia, M.N., 2005. Spatio-temporal distribution of the dominant diatom and dinoflagellate species in the Bay of Tunis (SW Mediterranean Sea). Mediterranean Marine Sciences 6, 17-34.

De Casabianca, M.L., Laugier, T., Marinho-Soriana, E., 1997. Seasonal changes of nutrients in water and sediment in a Mediterranean lagoon with shellfish farming activity (Thau Lagoon, France). ICES Journal of Marine Sciences 54, 905-916

De Madariaga, I., Joint, I., 1994. Photosynthesis and carbon metabolism by size-fractionated phytoplankton in the southern North Sea in early summer. Continental Shelf Research 14, 295-311.

Feller, R.J., Warwick, R.M., 1988. 13. Energetics. In: Higgings, R.P., Thiel, H. (Eds.), Introduction to the study of meiofauna. Smithsonian Institution Press, Washington, DC, pp. 181-196.

Fernández, M., Bianchi, M., Van Wambeke, K., 1994. Bacterial biomass, heterotrophic production and utilization of dissolved organic matter photosynthetically produced in the Almeria-Oran Front. Journal of Marine Systems 5, 313-325.

Flindt, M.R., Kamp-Nielsen, L., Marques, J.C., Pardal, M.A., Bocci, M., Bendoricchio, G., Salomonsen, J., Nielsen, S.N., Jørgensen, S.E., 1997. Description of the three shallow estuaries: Mondego River (Portugal), Roskilde Fjord (Denmark) and the Lagoon of Venice (Italy). Ecological Modelling 102, 1713.

Fonda Umani, S., Beran, A., 2003. Seasonal variations in the dynamics of microbial plankton communities: first estimates from experiments in the Gulf of Trieste, Northern Adriatic Sea. Marine Ecology Progress Series 247, 1-16. 
Fonda Umani, S., Tirelli, V., Beran, A., Guardiana, B., 2005. Relationships between microzooplankton and mesozooplankton: competition versus predation on natural assemblages of the Gulf of Trieste (northern Adriatic Sea). Journal of Plankton Research 27, 973-986.

Froneman, P.W., Perissinotto, R., McQuaid, C.D., 1996. Seasonal variations in microzooplankton grazing in the region of the Subtropical Convergence. Marine Biology 126, 433-442.

Gamito, S., Gilabert, J., Diego, C., Pérez-Ruzafa, M., 2005. Effect of changing environmental conditions on lagoon ecology. In: Gönenç, I.E., Wolflin, J.P. (Eds.), Coastal lagoons: Ecosystems processes and modeling for sustainable use and development. CRC Press, Boca Raton, pp. 193-223.

Gasol, J.M., Doval, M.D., Pinhassi, J., Calderón-Paz, J.I., Guixa-Boixareu, N., Vaqué, D., PedrósAliós, C., 1998. Diel variations in bacterial heterotrophic activity and growth in the northwestern Mediterranean Sea. Marine Ecology Progress Series 164, 107-124.

Gilabert, J., 2001. Seasonal plankton dynamics in a Mediterranean hypersaline coastal lagoon: the Mar Menor. Journal of Plankton Research 23, 207-217.

Goldman, J.C., Caron, D.A., Andersen, O.K., Dennett, M.R., 1987. Nutrient cycling in a microflagellate food chain: I. Nitrogen dynamics. Marine Ecology Progress Series 24, 231-242.

Gómez, F., Gorsky, G., 2003. Annual microplankton cycles in Villefranche Bay, Ligurian Sea, NW Mediterranean. Journal of Plankton Research 25, 323-339.

Gradinger, R., Friedrich, C., Spindler, M., 1999. Abundance, Biomass and composition of the sea ice biota of the Greenland Sea pack ice. Deep-Sea Research Part II Top Studies of Oceanography 46, 1457-1472.

Hamdi, H., Ghribi, R., Daly-Yahia, M.N., 2002. Fluctuations printanières et estivales des communautés de copépodes pélagiques dans la lagune de Bizerte. Revue de la FSB 1, 200-207.

Hansen, P.J., 1992. Prey size selection, feeding rates and growth dynamics of heterotrophic dinoflagellates with special emphasis of Gyrodinium spirale. Marine Biology 114, 327-334.

Hansen, P.J., Calado, A.J., 1999. Phagotrophic mechanisms and prey selection in free-living dinoflagellates. Journal of Eukaryote Microbiology 146, 382-389.

Harris, R., Wiebe, P., Lenz, J., Skjoldal, H.R., Huntley, M., 2000. ICES Zooplankton Methodology Manual, Academic Press, London, 300 pp.

Harzallah, A., 2003. Transport de polluants dans la lagune de Bizerte simulé par un modèle de circulation de l'eau. Bulletin de l'Institut National des Sciences et Technologie de la Mer, Salambôo 30, 1-19

Hillebrand, H., Dürselen, C.D., Kirschtel, D., Pollingher, U., Zohary, T., 1999. Biovolume calculation for pelagic and benthic microalgae. Journal of Phycology 35, 403-424.

Holmes, R.W., 1970. The Secchi disk in turbid coastal water. Limnology and Oceanography 15, 688694.

Jespersen, H., Olsen, K., 1982. Bioenergetics in veliger larvae of Mytilus edulis L. Ophelia 21, 101113.

Jürgens, K., Skibbe, O., Jeppesen, E., 1999. Impact of metazooplankton on the composition and population dynamics of planktonic ciliates in a shallow, hypertrophic lake. Aquatic Microbial Ecology 17, 61-75.

Khessiba, A., Hoarau, P., Gnassia-Barelli, M., Aïssa, P., Roméo, M., 2001. Biochemical response of the mussel Mytilus galloprovincialis from Bizerta (Tunisia) to chemical pollutant exposure. Archive of Environmental Contaminant Toxicology 40, 222-229.

Knap, A., Michaels, A., Close, A., Ducklow, H., Dickson, A., 1994. Protocols for the Joint Global Ocean Flux Study (JGOFS) Core Measurements. JGOFS Report Nr. 19, Reprint of the IOC Manuals and Guides No. 29, UNESCO, 170 pp.

Lam-Hoai, T., Rougier, C., 2001. Zooplankton assemblage and biomass during a 4-period survey in a northern Mediterranean coastal lagoon. Water Research 35, 271-283.

Landry, M.R., Hassett, R.P., 1982 Estimating the grazing impact of marine micro-zooplankton. Marine Biology 67, 283-288.

Larsen, J., Sournia, A., 1991. The diversity of heterotrophic dinoflagellates. In: Patterson, D.J.P., Larsen, J. (Eds.), The biology of free-living heterotrophic flagellates. Clarendon Press, Oxford, pp. 313-331.

Leakey, R.J.G., Burkill, P.H., Sleigh, M.A., 1994. A comparison of fixatives for the estimation of abundance and biovolume of marine planktonic ciliate populations. Journal of Plankton Research 16, 375-389.

Legendre, L., Rassoulzadegan, F., 1995. Plankton and nutrient dynamics in marine waters. Ophelia 41, 153-172

Lessard, E.J., Swift, E., 1985. Species-specific grazing rates of heterotrophic dinoflagellates in oceanic waters, measured with a dual-label radioisotope technique. Marine Biology 87, 289-296. 
Lorenzen, C.J. 1967. Determination of chlorophyll and pheopigments by spectrophotometric equations. Limnology and Oceanography 12, 343-346.

Lund, J.W.G., Kipling, C., LeCren, E.D., 1958. The inverted microscope method of estimating algal numbers and statistical basis of estimations by counting. Hydrobiologia 11, 143-170.

Maclsaac, E.A., Stockner, J.G., 1993. Enumeration of phototrophic picoplankton by autofluorescence microscopy. In: Kemp, P.F., Sherr, B.F., Sherr, E.B., Cole, J.J. (Eds.), Handbook of Methodology in Aquatic Microbial Ecology. Lewis Publishers, Boca Raton, FL, pp. 187-197.

Magazzù, G., Decembrini, F., 1995. Primary production, biomass and abundance of phototrophic picoplankton in the Mediterranean sea: a review. Aquatic Microbial Ecology 9, 97-104.

Menden-Deuer, S., Lessard, E.J., 2000. Carbon volume relationships for dinoflagellates, diatoms and other protest plankton. Limnology and Oceanography 45, 569-579.

Michel, C., Nielsen, T.G., Nozais, C., Gosselin, M., 2002. Significance of sedimentation and grazing by ice micro- and meiofauna for carbon cycling in annual sea ice (northern Baffin Bay). Aquatic Microbial Ecology 30, 57-68.

Moigis, A.G., 2000. Photosynthetic rates in the surface waters of the Red Sea: the radiocarbon vs. the non-isotopic dilution method. Journal of Plankton Research 22, 713-727.

Morán, X.A.G., Taupier-Letage, I., Vázquez-Domínguez, E., Ruiz, S., Arin, L., Raimbault, P., Estrada, M., 2001. Physical-biological coupling in the Algerian Basin (SW Mediterranean): Influence of mesoscale instabilities on the biomass and production of phytoplankton and bacterioplankton. Deep Sea Research I 48, 405-437.

Mullin, J.B., Riley, J.P., 1955. The colorimetric determination of silicate with special reference to sea and natural waters. Analytica Chemica Acta 12, 162-176.

Mullin, M.M., Sloan, P.R., Eppley, R.W., 1966. Relationship between carbon content, cell volume and area in phytoplankton. Limnology and Oceanography 11, 307-311.

Murphy, J., Riley, J.P., 1962. A modified single solution method for the determination of phosphate in natural waters. Analytica Chemica Acta 27, 31-36.

Murrell, M.C., Hollibaugh, J.T., 1998. Microzooplankton grazing in northern San Francisco Bay measured by the dilution method. Aquatic Microbial Ecology 15, 53-63.

Mzoughi, N., Hellal, F., Dachraoui, M., Villeneuve, J.P., Cattini, C., de Mora, S.J., El Abed, A., 2002. Méthodologie de l'extraction des hydrocarbures aromatiques polycycliques. Application à des sédiments de la lagune de Bizerte (Tunisie). Comptes Rendus Geosciences 334, 893-901.

Nielsen, T.G., Løkkegaard, B., Richardson, K., Pedersen, F.B., Hansen, L. 1993. Structure of plankton communities in the Dogger Bank area (North Sea) during a stratified situation. Marine Ecology Progress Series 95, 115-13

Nuccio, C., Melillo, C., Massi, L., Innamorati, M., 2003. Phytoplankton abundance, community structure and diversity in the eutrophicated Orbetello lagoon (Tuscany) from 1995 to 2001. Oceanologica Acta 26, 15-25.

Omori, M., 1969. Weight and Chemical composition of some important oceanic zooplankton in the North Pacific Ocean. Marine Biology 3, 4-10.

Parsons, T.R., Maita, Y., Lalli, C.M., 1984. A manual of chemical and biological methods for seawater analysis. Pergamon Press, Oxford, $171 \mathrm{pp}$

Pedrós-Alió, C., Calderón-Paz, J.I., Guixa-Boixereu, N., Estrada, M., Gasol, J.M., 1999. Bacterioplankton and phytoplankton biomass and production during summer stratification in the northwestern Mediterranean Sea. Deep Sea Research I 46, 985-1019.

Porter, K.G., Feig, Y.S., 1980. The use of DAPI for identifying and counting aquatic microflora. Limnology and Oceanography 25, 943-948.

Putt, M., Stoecker, D.K., 1989. An experimentally determined carbon:volume ratio for marine oligotrichous ciliates from estuarine and coastal waters. Limnology and Oceanography 34, 1097-1103. Ramfos, A., Isari, S., Somarakis, S., Georgopoulos, D., Koutsikopoulos, C., Fragopoulu, N., 2006. Mesozooplankton community structure in offshore and coastal waters of the Ionian Sea (eastern Mediterranean) during mixed and stratified conditions. Marine Biology 150, 29-44.

Rassoulzadegan, F., 1993. Protozoan patterns in the Azam-Ammerman's bacterial-phytoplankton mutualism. In: Guerrero, R., Pedros-Alio, C. (Eds), Trends in microbial ecology. Spanish Society for Microbiology, Barcelone, pp. 435-439

Riemann, F., Ernst, W., Ernst, R., 1990. Acetate uptake from ambient water by the free-living marine nematode Adoncholaimus thalassophygas. Marine Biology 104, 453-457.

Robinson, C., 2000. Plankton gross production andrespiration in the shallow water hydrothermal systems of Milos, Aegean Sea. Journal of Plankton Research 22, 887-906.

Rougier, C., Lam Hoai, T., 1997. Biodiversity through two groups of microzooplankton in a coastal lagoon (Etang de Thau). Vie Milieu 47, 387-394. 
Sakka, A., Legendre, L., Gosselin, M., Delesalle, B., 2000. Structure of the oligotrophic planktonic food web under low grazing of heterotrophic bacteria: Takapoto Atoll, French Polynesia. Marine Ecology Progress Series 197, 1-17.

Sakka Hlaili, A., Chikhaoui, M.A., El Grami, B., Hadj Mabrouk, H., 2006. Effects of N and P supply on phytoplankton in Bizerte Lagoon (western Mediterranean). Journal of Experimental Marine Biology and Ecology 333, 79-96.

Sakka Hlaili, A., Grami, B., Hadj Mabrouk, H., Gosselin, M., Hamel, D., 2007. Phytoplankton growth and microzooplankton grazing rates in a restricted Mediterranean lagoon (Bizerte Lagoon, Tunisia); Marine Biology 151, 767-783.

Sheldon, R.W., Nival, P., Rassoulzadegan, F., 1986. An experimental investigation of a flagellateciliate-copepod food chain with some observations relevant to the linear biomass hypothesis. Limnology and Oceanography 31, 184-188.

Sherr, E.B., Sherr, B.F., 1993. Preservation and storage of samples for enumeration of heterotrophic protests. In: Kemp, P.F., Sherr, B.F., Sherr, E.B., Cole, J.J. (Eds.), Handbook of Methods in Aquatic Microbial Ecology. Lewis Publishers, London, pp. 207-212.

Shinada, A., Ban, S., Ikeda, T., 2003. Seasonal changes in Nano/Micro-Zooplankton Herbivory and Heterotrophic Nano-Flagellates Bacterivory off Cape Esan, Southern Hokkaido, Japan. Journal of Oceanography 59, 609-618.

Šimek, K., Bobkova, J., Macek, M., Nedoma, J., Psenner, R., 1995. Ciliate grazing on picoplankton in an eutrophic reservoir during the summer phytoplankton maximum: a study at the species and community level. Limnology and Oceanography 40, 1077-1090.

Sime-Ngando, T., Gosselin, M., Roy, S., Chanut, J.P., 1995. Significance of planktonic ciliated protozoa in the Lower St. Lawrence Estuary: comparison with bacterial, phytoplankton, and particulate organic carbon. Aquatic Microbial Ecology 9, 243-258.

Sommer, F., Stibor, H., Sommer, U., Velimirov, B., 2000. Grazing by mesozooplankton from Kiel Bight, Baltic Sea, on different sized algae and natural seston size fractions. Marine Ecology Progress Series $199,43-53$

Solidoro, C., Pastres, R., Cossarini, G., 2005. Nitrogen and plankton dynamics in the lagoon of Venice. Ecological Modeling 184, 103-124.

Søndergaard, M., Jensen, L.M., Ærtebrjerg, G., 1991. Picoalgae in Danish coastal waters during summer stratification. Marine Ecology Progress Series 79, 139-149.

Souissi, S., Daly-Yahia Kéfi, O., Daly-Yahia, M.N., 2000. Spatial characterization of nutrient dynamics in the Bayof Tunis (south-western Mediterranean) using multivariate analyses: consequence for phytoand zooplankton distribution. Journal of Plankton Research 22, 2039-2059.

Stelfox-Widdicombe, C.E., Archer, S.D., Burkill, P.H., Stefels, J., 2004. Microzooplankton grazing in Phaeocystis and diatom-dominated waters in the southern North Sea in spring. Journal of Sea Research 51, 37-51.

Stoecker, D.K., Gifford, D.J., Putt, M., 1995. Preservation of marine planktonic ciliates: losses and cell shrinkage during fixation. Marine Ecology Progress Series 110, 293-299.

Stoecker, D.K., 1999. Mixotrophy among dinoflagellates. Journal of Eukaryote Microbiology 46, 397401.

Straile D., 1997 Gross growth efficiencies of protozoan and metazoan zooplankton and their dependence on food concentration, predator-prey weight ratio, and taxonomic group. Limnology and Oceanography 42, 1375-1385.

Strom, S.L., Morello, T.A., 1998. Comparative growth rates and yields of ciliates and heterotrophic dinoflagellates. Journal of Plankton Research 20, 571-585.

Stumm, W., Baccini, P., 1983. Man-made chemical perturbations of lakes. In: Lerman, A. (Ed.), Lakes, Chemistry, Geology, Physics. Springer-Verlag, New York, pp. 91-126.

Turner, J.T., 2002. Zooplankton faecal pellets, marine snow and sinking phytoplankton blooms. Aquatic Microbial Ecology 27, 57-102.

Vaquer, A., Troussellier, M., Courtis, C., Bibent, B. 1996. Standing stock and dynamics of picophytoplankton in the Thau Lagoon (northwest Mediterranean coast). Limnology Oceanography 41, 1821-1828.

Vézina, A.F., Platt, T. 1988. Food web dynamics in the ocean. I. Best estimate of flow networks using inverse methods. Marine Ecology Progress Series 42, 269-287

Vaulot, D., Partensky, F., Neveux, J., Mantoura, R.F.C., Llewellyn, C.A., 1990. Winter presence of prochlorophytes in surface waters of the northwestern Mediterranean Sea. Limnology Oceanography 35, 1156-1164.

Wood, E.D., Armstrong, F.A.J., Richards, F.A., 1967. Determination of nitrate in seawater by cadmium-copper reduction to nitrite. Journal of Marine Biology Association UK 47, 23-31. 


\section{Figures}

Fig. 1 Location of the sampling stations in Bizerte lagoon.

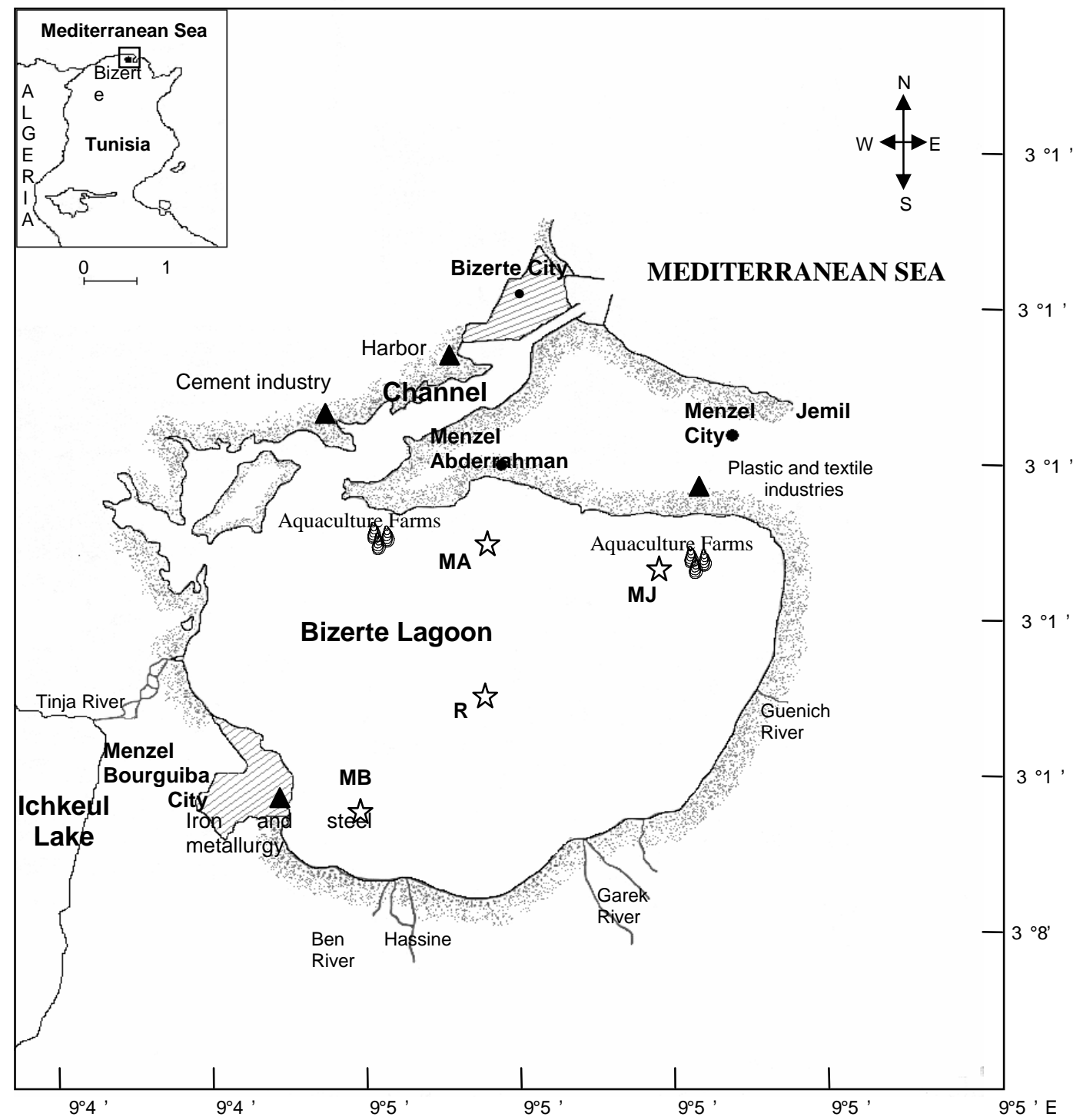

Fig. 1 
Fig. 2. Vertical profiles of biomasses for the different planktonic groups in the sampling stations (Means $\pm \mathrm{SD}$ ).

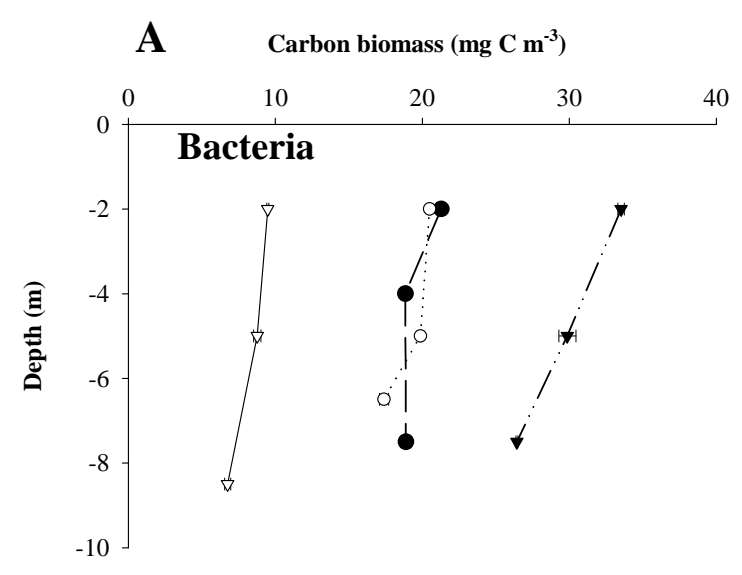

B Carbon biomass $\left(\mathrm{mg} \mathrm{C} \mathrm{m}^{-3}\right)$

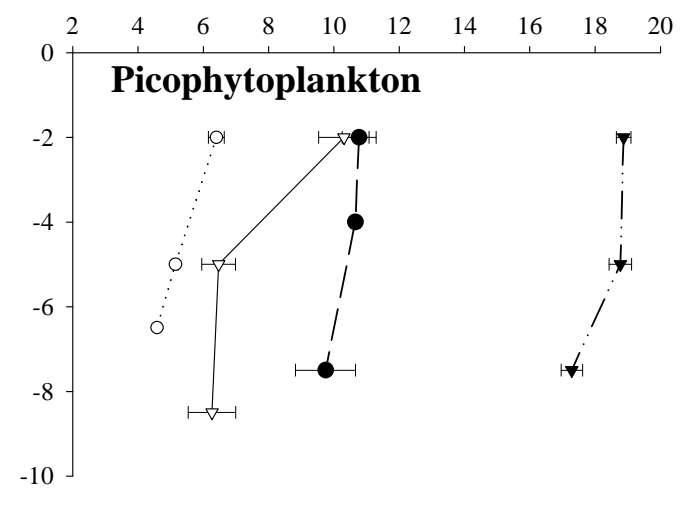

C Carbon biomass $\left(\mathrm{mg} \mathrm{C} \mathrm{m}^{-3}\right)$

D Carbon biomass $\left(\mathrm{mg} \mathrm{C} \mathrm{m}^{-3}\right)$
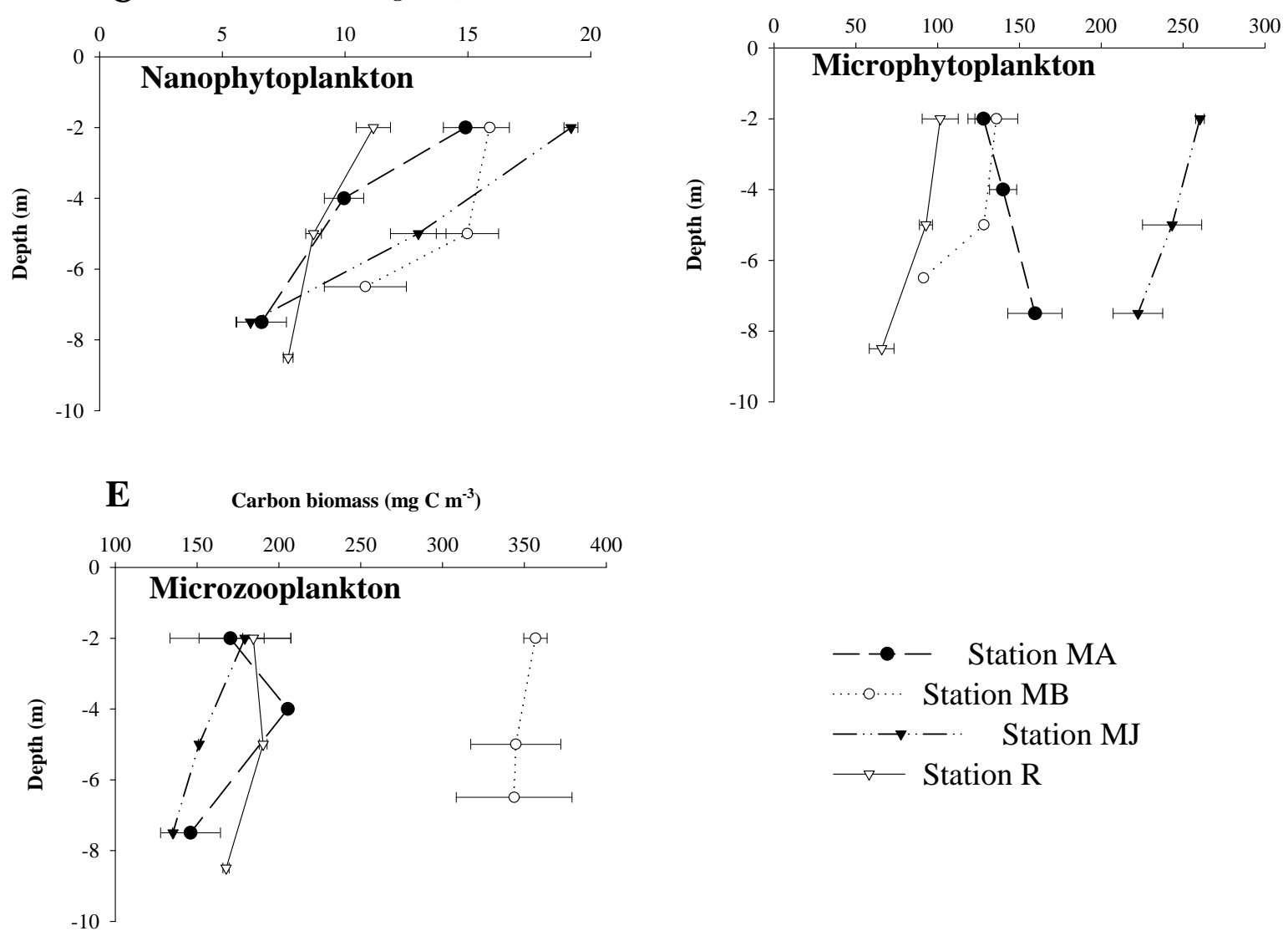

Fig. 2 
Fig. 3. Taxonomic composition of $\geq 2 \mu \mathrm{m}$ phytoplankton determined at each sampling depth for the studied stations.
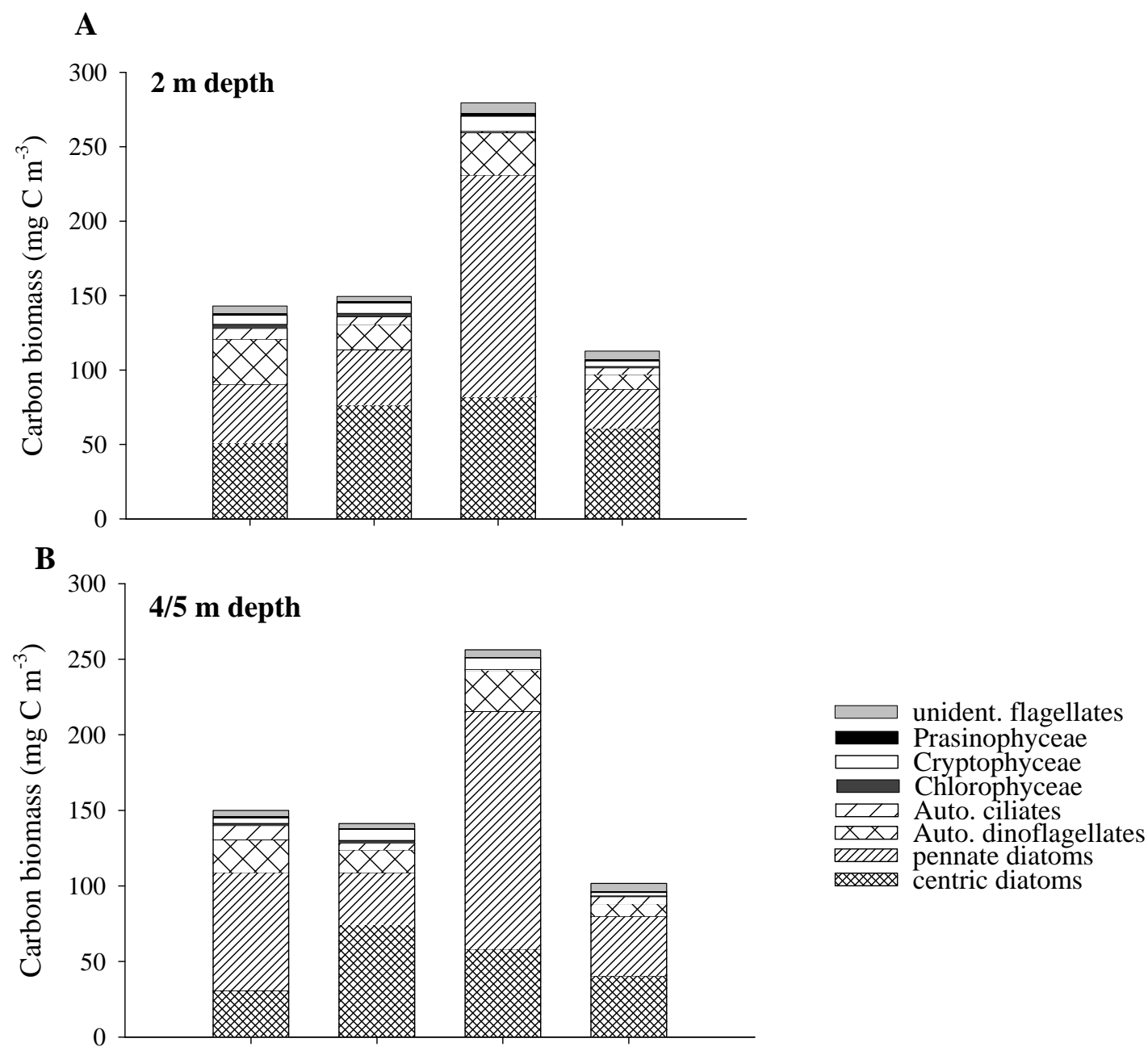

C

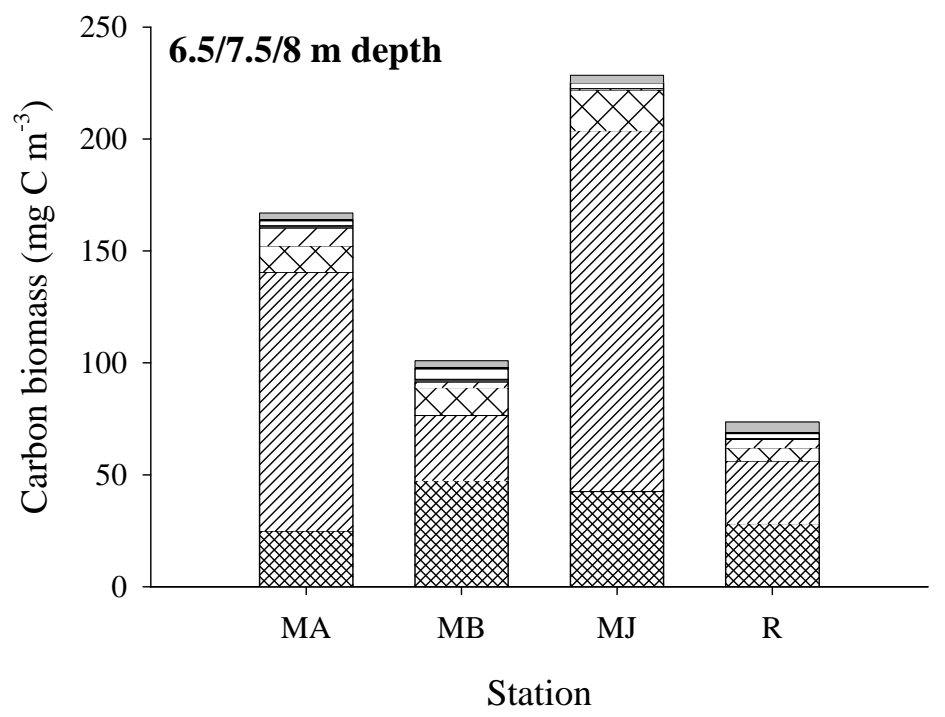

Fig. 3 
Fig. 4. Taxonomic composition of microzooplankton determined at each sampling depth for the studied stations.

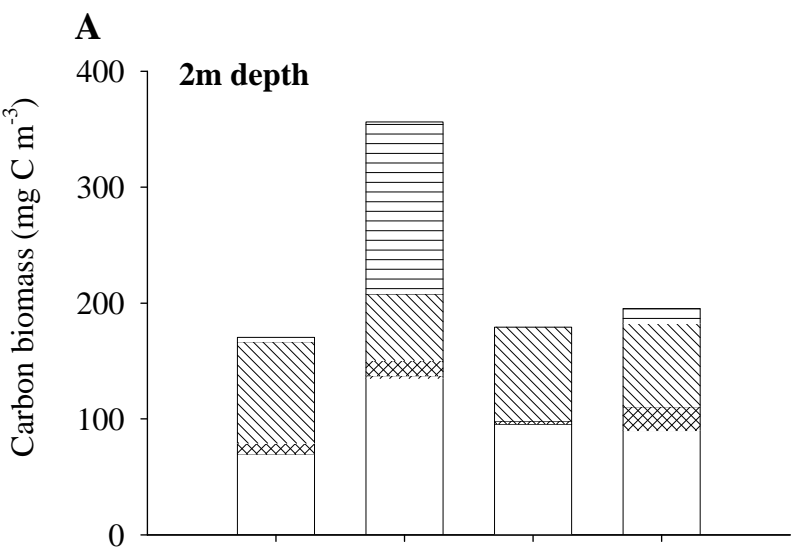

$$
\text { B }
$$

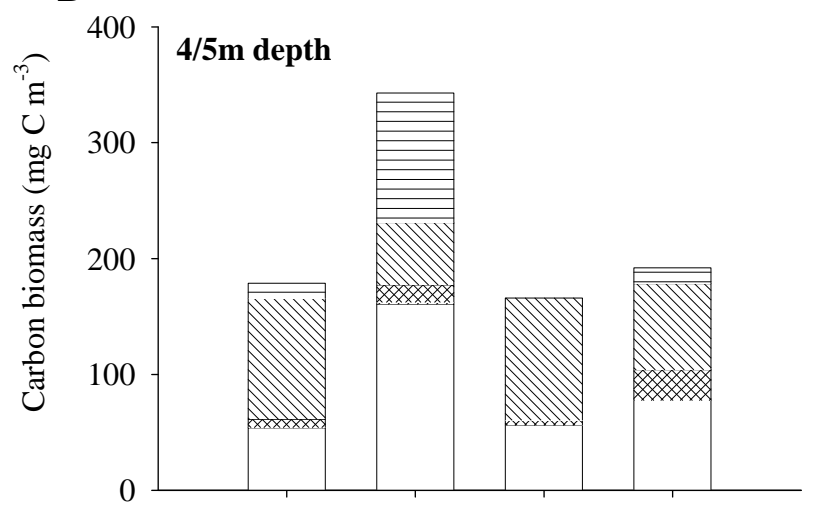

C

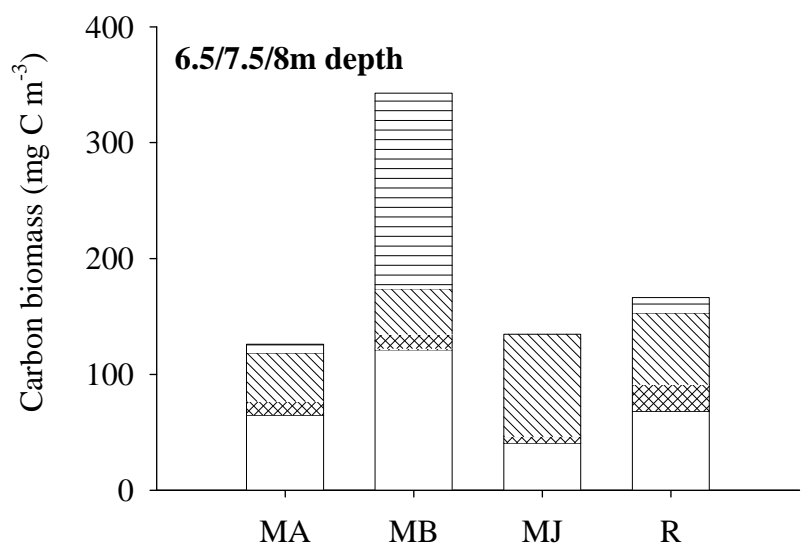

Station

Fig. 4 
Fig. 5. Taxonomic composition of mesozooplankton determined at the sampling stations.

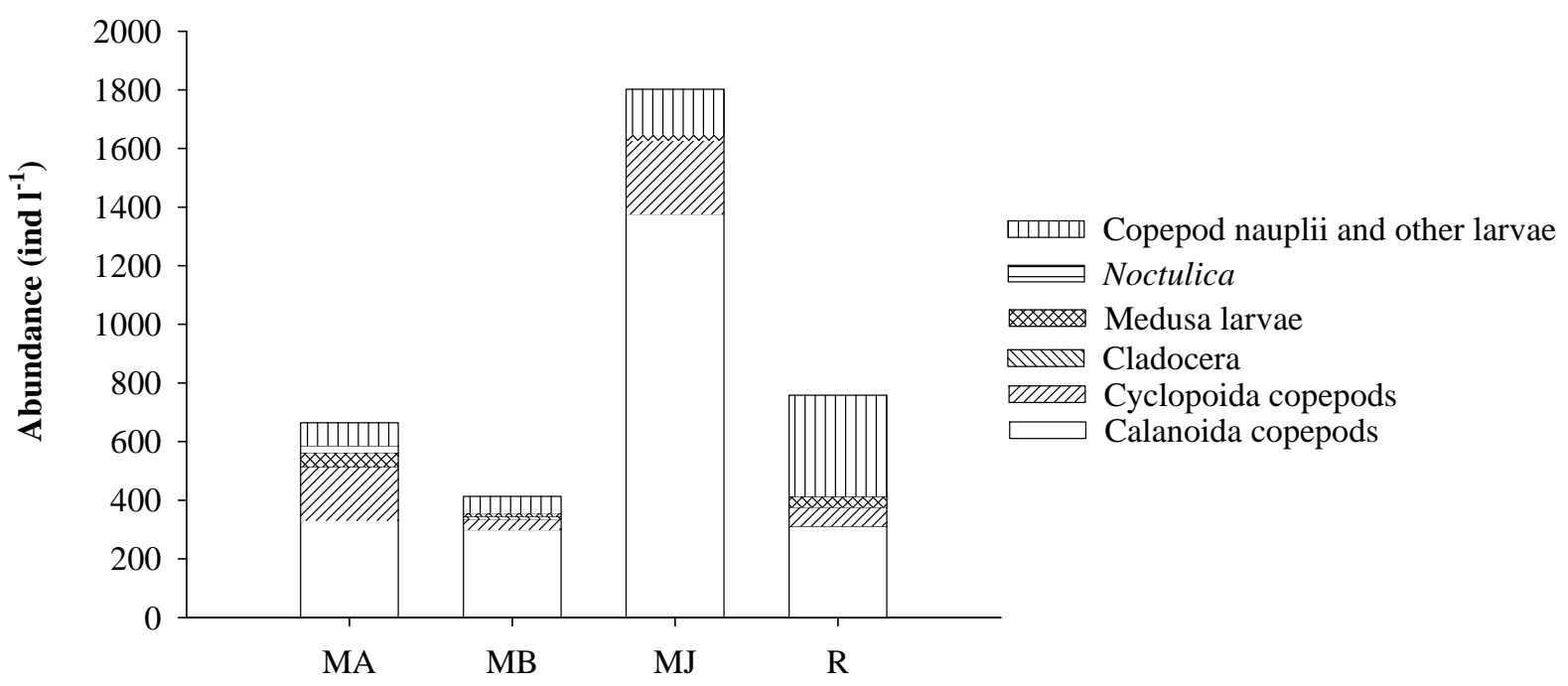

Station

Fig. 5 
Fig. 6. Trophic interactions between planktonic components within food webs at each sampling station in the Bizerte lagoon during summer. Carbon biomass $\left(B, \mathrm{mg} \mathrm{C} \mathrm{m}^{-3}\right)$, carbon production $(P$, as

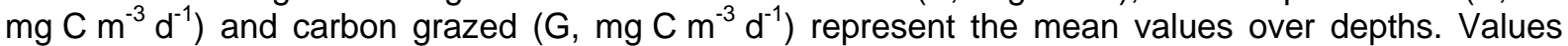
given with arrows represent percentages of consumed production.

A

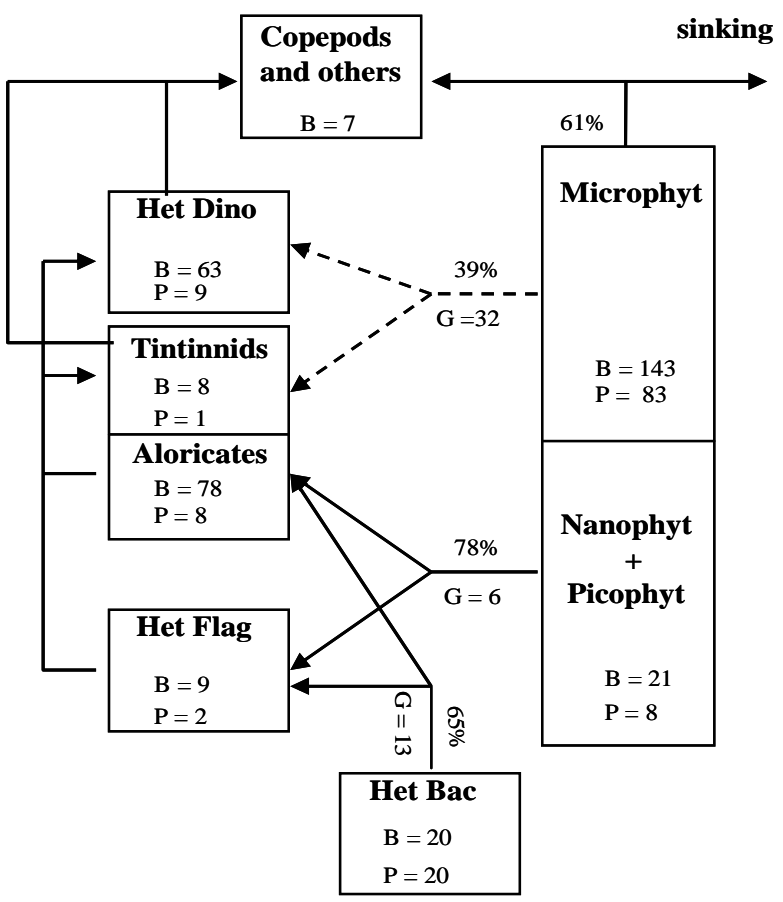

C

Station MB

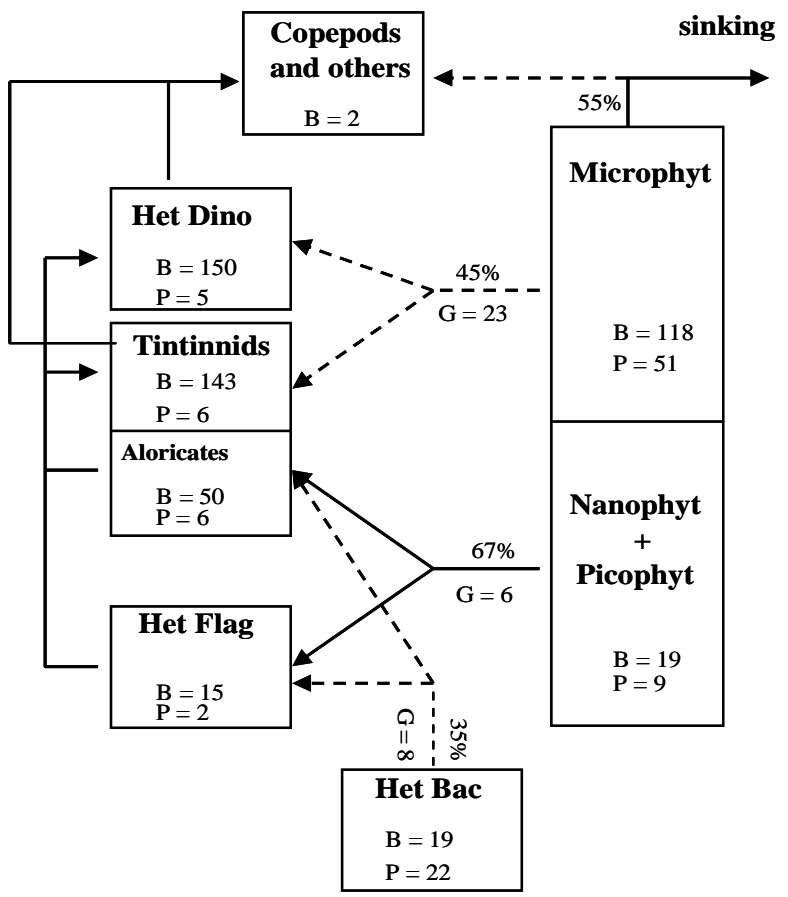

B

Station MJ

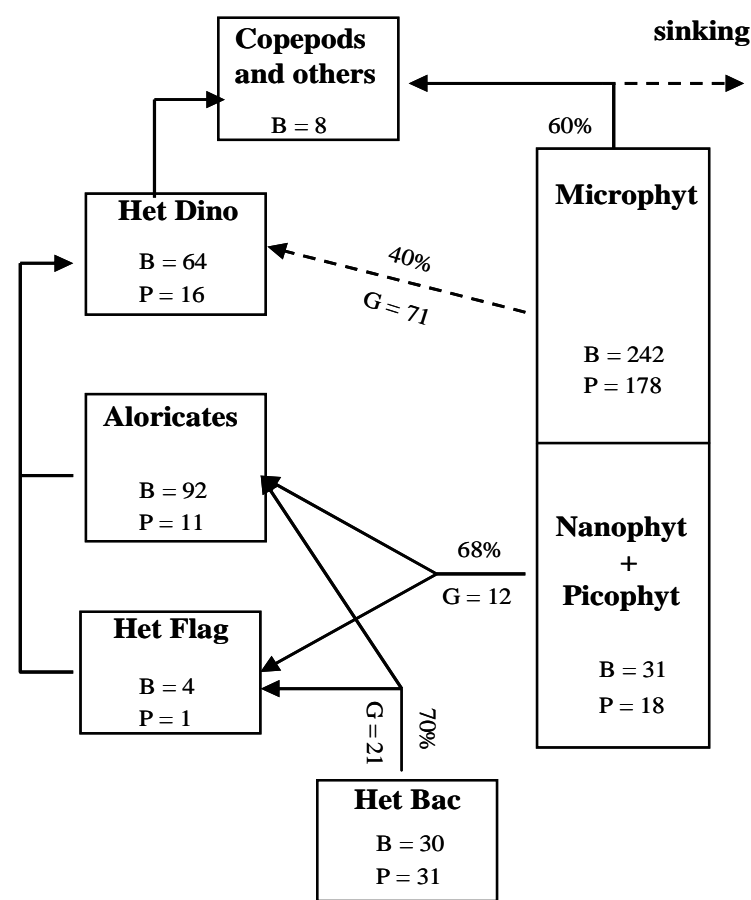

D Station $\mathbf{R}$

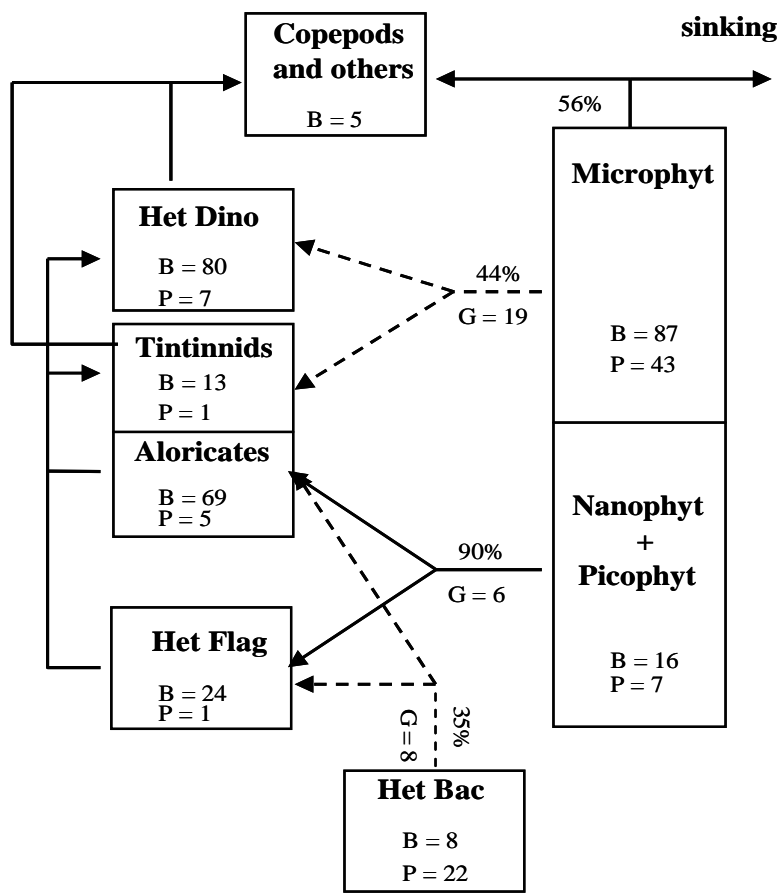

Fig. 6 
Tables

Table 1

Location, maximal depth, depth of the $10 \%$ isolume $\left(Z_{\mathrm{eu}}\right)$ and sampling dates and depths for each studied station

\begin{tabular}{|c|c|c|c|c|c|c|}
\hline \multirow[b]{2}{*}{ Station } & \multicolumn{2}{|l|}{ Location } & \multirow{2}{*}{$\begin{array}{l}\text { Max. depth } \\
\text { (m) }\end{array}$} & \multirow[b]{2}{*}{$\begin{array}{l}Z_{\text {eu }} \\
(\mathrm{m})\end{array}$} & \multirow{2}{*}{$\begin{array}{l}\text { Sampling } \\
\text { dates }\end{array}$} & \multirow{2}{*}{$\begin{array}{l}\text { Sampling } \\
\text { depths (m) }\end{array}$} \\
\hline & $\begin{array}{l}\text { Latitude } \\
\left({ }^{\circ} \mathrm{N}\right)\end{array}$ & $\begin{array}{l}\text { Longitude } \\
\left({ }^{\circ} \mathrm{E}\right)\end{array}$ & & & & \\
\hline$M A^{(a)}$ & $37^{\circ} 13.105^{\prime}$ & $9^{\circ} 51.823^{\prime}$ & 9.4 & 4.8 & 13/15 July & $2.0,4.0,7.5$ \\
\hline $\mathrm{MB}^{(\mathrm{b})}$ & $37^{\circ} 09.633^{\prime}$ & $9^{\circ} 49.959^{\prime}$ & 8.2 & 8.0 & 17/19 July & $2.0,4.0,6.5$ \\
\hline $\mathrm{MJ}^{(\mathrm{c})}$ & $37^{\circ} 12.305^{\prime}$ & $9^{\circ} 53.857^{\prime}$ & 9.2 & 8.0 & 13/15 July & $2.0,5.0,7.5$ \\
\hline $\mathrm{R}^{(\mathrm{d})}$ & $37^{\circ} 11.190^{\prime}$ & $9^{\circ} 51.547^{\prime}$ & 10.0 & 8.0 & $18 / 20$ July & $2.0,5.0,8.5$ \\
\hline
\end{tabular}

(a) Station impacted by urban effluents

(b) Station impacted by industrial effluents

(c) Station located in the aquaculture area

(d) Central station

Table 2

Vertical distribution of temperature $(\mathrm{T})$, salinity $(\mathrm{S})$, concentrations of nutrients $\left(\mathrm{NO}_{2}{ }^{-}, \mathrm{NO}_{3}{ }^{-}, \mathrm{NH}_{4}{ }^{+}, \mathrm{PO}_{4}{ }^{3-}\right.$ , $\mathrm{Si}(\mathrm{OH})_{4}$ ), dissolved organic carbon (DOC) and $\mathrm{Chl} a$ in the study stations. Values in parentheses are percents $<2 \mu \mathrm{m} \mathrm{Chl} \mathrm{a} \mathrm{fraction.}$

\begin{tabular}{|c|c|c|c|c|c|c|c|c|c|c|}
\hline Station & $\begin{array}{l}\text { Depth } \\
(\mathrm{m})\end{array}$ & $\begin{array}{l}\mathrm{T} \\
\left({ }^{\circ} \mathrm{C}\right) \\
\end{array}$ & $S$ & $\begin{array}{l}\mathrm{NO}_{2}^{-} \\
(\mu \mathrm{M})\end{array}$ & $\begin{array}{l}\mathrm{NO}_{3}^{-} \\
(\mu \mathrm{M})\end{array}$ & $\begin{array}{l}\mathrm{NH}_{4}^{+} \\
(\mu \mathrm{M})\end{array}$ & $\begin{array}{l}\mathrm{PO}_{4}^{3-} \\
(\mu \mathrm{M})\end{array}$ & $\begin{array}{l}\mathrm{Si}(\mathrm{OH})_{4} \\
(\mu \mathrm{M})\end{array}$ & $\begin{array}{l}\text { DOC } \\
(\mu \mathrm{M})\end{array}$ & $\begin{array}{l}\text { Chl a } \\
\left(\mathrm{mg} \mathrm{m}^{-3}\right)\end{array}$ \\
\hline \multirow{3}{*}{ MA } & 2.0 & 25.4 & 36.1 & 0.39 & 1.50 & 13.71 & 0.32 & 5.21 & 152.27 & $\begin{array}{l}4.73 \\
(58)\end{array}$ \\
\hline & 4.0 & 25.0 & 36.2 & 0.51 & 1.65 & 11.26 & 1.62 & 3.20 & 165.52 & $\begin{array}{l}3.45 \\
(50)\end{array}$ \\
\hline & 7.5 & 25.2 & 36.1 & 0.45 & 1.87 & 8.41 & 0.75 & 5.63 & 165.52 & $\begin{array}{l}2.10 \\
(40)\end{array}$ \\
\hline \multirow{4}{*}{ MB } & 2.0 & 25.2 & 36.2 & 0.58 & 3.20 & 11.35 & 0.13 & 4.78 & 169.58 & $\begin{array}{l}2.94 \\
(38)\end{array}$ \\
\hline & 4.0 & 25.4 & 36.1 & 0.54 & 3.20 & 6.65 & 0.54 & 5.37 & 159.47 & $\begin{array}{l}2.53 \\
(40)\end{array}$ \\
\hline & 6.5 & 25.5 & 36.0 & 0.26 & 2.40 & 0.18 & 0.24 & 6.90 & 169.18 & $\begin{array}{l}1.93 \\
(44)\end{array}$ \\
\hline & 2.0 & 24.7 & 36.2 & 0.30 & 3.38 & 14.21 & 0.86 & 13.30 & 168.33 & $\begin{array}{l}5.48 \\
(58)\end{array}$ \\
\hline \multirow[t]{2}{*}{ MJ } & 5.0 & 25.0 & 36.3 & 0.66 & 4.56 & 5.47 & 1.33 & 12.30 & 173.69 & $\begin{array}{l}4.43 \\
(50)\end{array}$ \\
\hline & 7.5 & 25.4 & 36.2 & 0.48 & 5.30 & 0.76 & 0.45 & 11.71 & 175.67 & $\begin{array}{l}3.31 \\
(49)\end{array}$ \\
\hline \multirow{3}{*}{$\mathrm{R}$} & 2.0 & 25.6 & 36.5 & 0.47 & 1.53 & 5.10 & 0.60 & 5.80 & 162.15 & $\begin{array}{l}4.99 \\
(56)\end{array}$ \\
\hline & 5.0 & 25.9 & 36.1 & 0.40 & 1.65 & 6.08 & 0.40 & 5.60 & 161.37 & $\begin{array}{l}4.21 \\
(53)\end{array}$ \\
\hline & 8.5 & 24.3 & 36.2 & 0.44 & 1.83 & 5.10 & 0.70 & 5.80 & 163.43 & $\begin{array}{l}3.29 \\
(51)\end{array}$ \\
\hline
\end{tabular}


Table 3

Analysis of variance (ANOVA) and pair-wise multiple comparison test (Student-Newman-Keuls method) concerning the effects of sampling station and depth on physico-chemical factors, biomasses of trophic groups and rates of production for bacteria and phytoplankton and of their grazing by microzooplankton. ${ }^{\star} 1 \%<\mathrm{P} \leq 5 \%,{ }^{\star \star} 0.1 \%<\mathrm{P} \leq 1 \%$ and ${ }^{* \star \star} \mathrm{P} \leq 0.1 \%$. ns: non significant

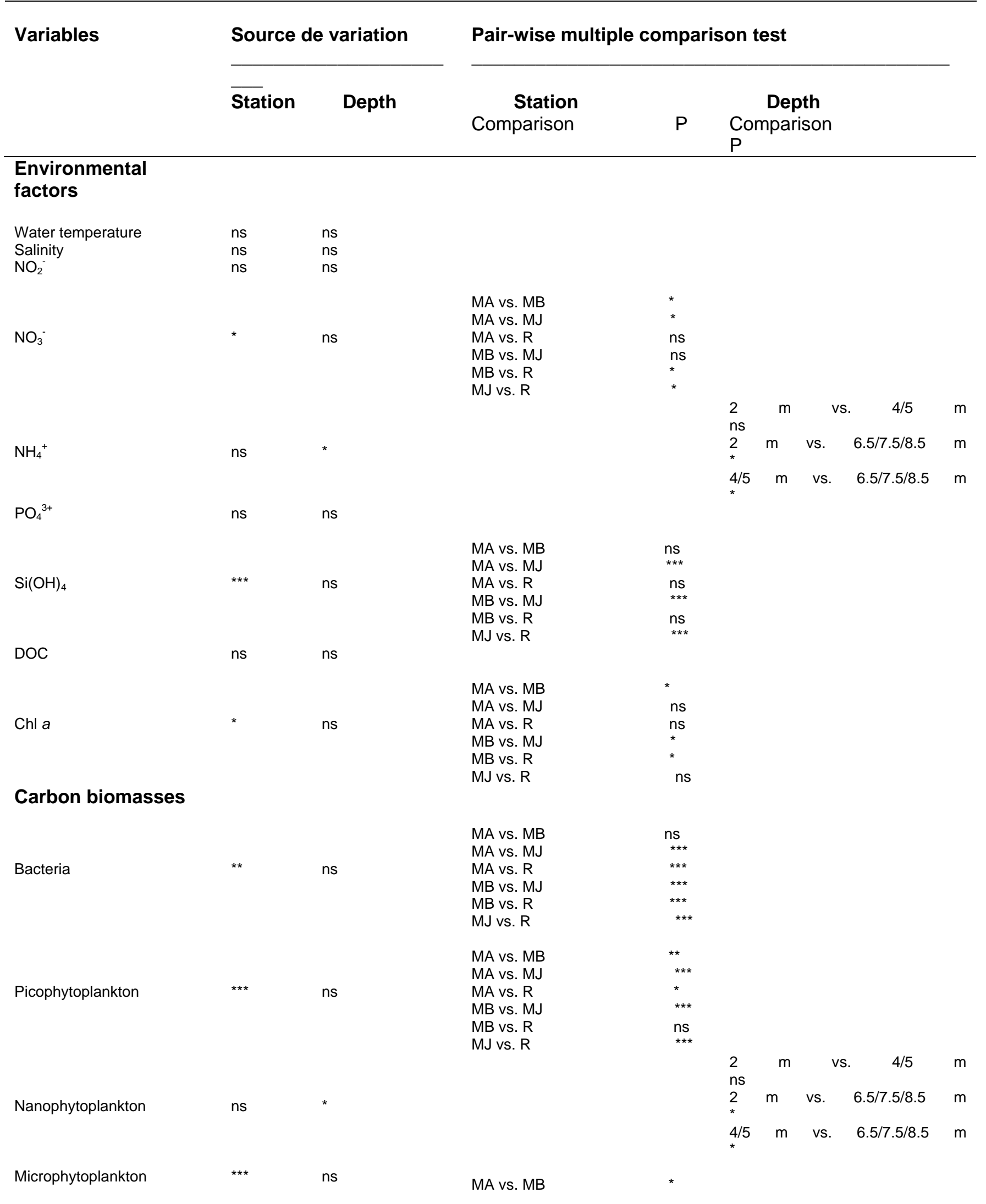




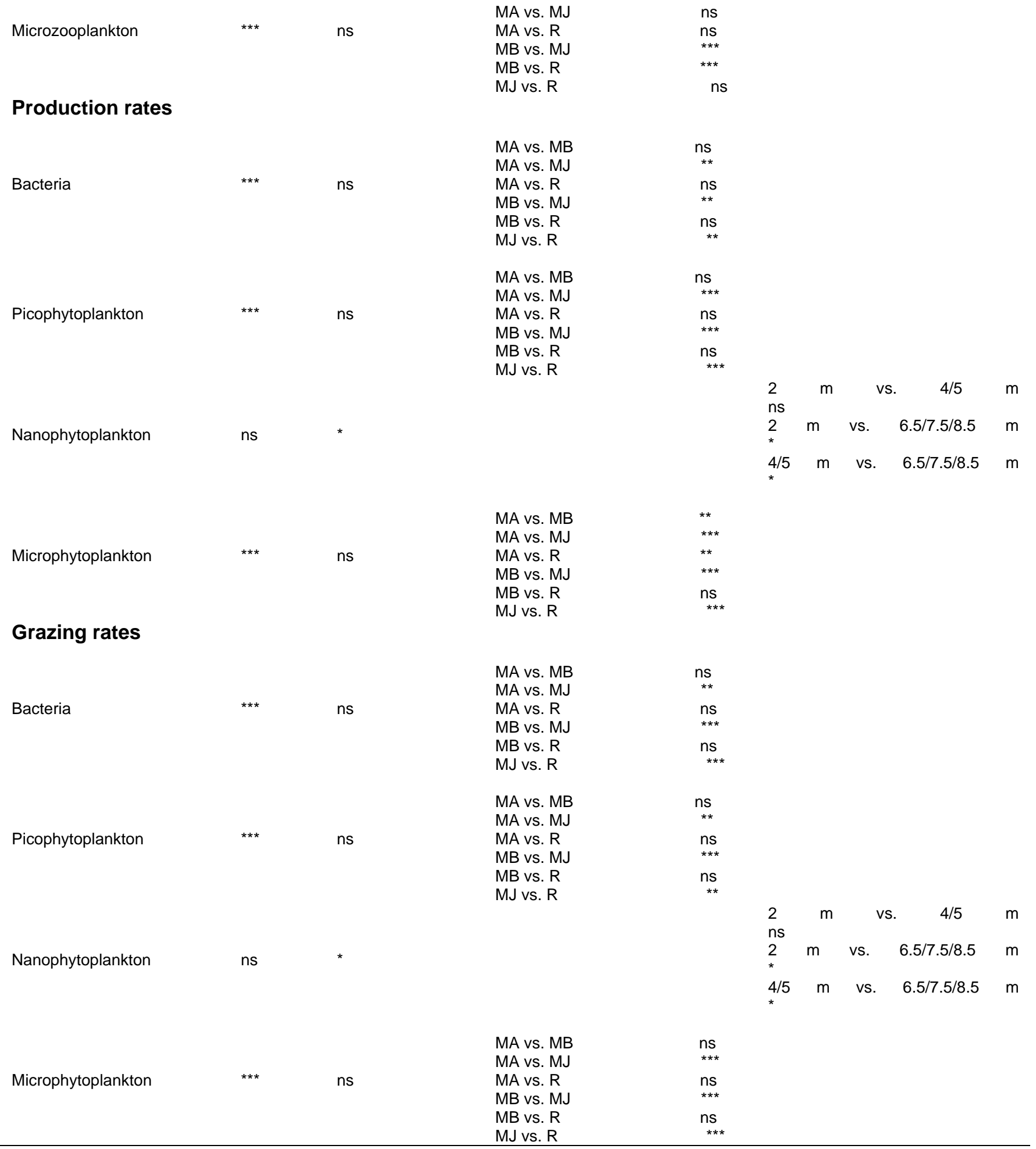


Table 4

Production and grazing rates for bacteria (Bac), picophytoplankton (Picophyt, <2 $\mu \mathrm{m}$ ), nanophytoplankton (Nanophyt, 2-10 $\mu$ m) and microphytoplankton

(Microphyt, 10-200 $\mu \mathrm{m}$ ) for each sampling depths in the different stations. (Mean \pm SD). Values in parentheses are the percentages (\%) of grazed production.

\begin{tabular}{|c|c|c|c|c|c|c|c|c|c|}
\hline \multirow{2}{*}{ Station } & \multirow{2}{*}{$\begin{array}{l}\text { Depth } \\
\text { (m) }\end{array}$} & \multicolumn{4}{|c|}{ Production rate $\left(\mathrm{mg} \mathrm{C} \mathrm{m}^{-3} \mathrm{~d}^{-1}\right)$} & \multicolumn{4}{|c|}{ Grazing rate $\left(\mathrm{mg} \mathrm{C} \mathrm{m}^{-3} \mathrm{~d}^{-1}\right)$} \\
\hline & & Bac & Picophyt & Nanophyt & Microphyt & Bac & Picophyt & Nanophyt & Microphyt \\
\hline \multirow{3}{*}{ MA } & 2.0 & $21.27 \pm 0.55$ & $2.39 \pm 0.04$ & $5.99 \pm 0.19$ & $74.39 \pm 14.6$ & $\begin{array}{l}12.05 \pm 2.13 \\
(56.5)\end{array}$ & $\begin{array}{l}1.77 \pm 0.12 \\
(74.0)\end{array}$ & $\begin{array}{l}3.62 \pm 1.13 \\
(60.8)\end{array}$ & $\begin{array}{l}27.87 \pm 3.64 \\
(37.7)\end{array}$ \\
\hline & 4.0 & $18.84 \pm 0.47$ & $2.36 \pm 0.05$ & $4.00 \pm 0.24$ & $81.24 \pm 14.00$ & $\begin{array}{l}12.93 \pm 0.65 \\
(68.7)\end{array}$ & $\begin{array}{l}2.20 \pm 0.70 \\
(92.6)\end{array}$ & $\begin{array}{l}2.88 \pm 0.19 \\
(72.3)\end{array}$ & $\begin{array}{l}37.18 \pm 4.15 \\
(47.0)\end{array}$ \\
\hline & 7.5 & $18.85 \pm 0.30$ & $2.15 \pm 0.05$ & $2.66 \pm 0.49$ & $91.61 \pm 1.67$ & $\begin{array}{l}12.0 \pm 1.54 \\
(63.1)\end{array}$ & $\begin{array}{l}1.44 \pm 0.63 \\
(67.0)\end{array}$ & $\begin{array}{l}1.36 \pm 0.27 \\
(51.0)\end{array}$ & $\begin{array}{l}31.01 \pm 3.6 \\
(34.0)\end{array}$ \\
\hline \multirow{3}{*}{ MB } & 2.0 & $23.07 \pm 1.06$ & $2.79 \pm 0.03$ & $6.29 \pm 0.52$ & $52.32 \pm 14.00$ & $\begin{array}{l}8.14 \pm 1.38 \\
(35.2)\end{array}$ & $\begin{array}{l}1.47 \pm 0.16 \\
(52.6)\end{array}$ & $\begin{array}{l}4.50 \pm 1.53 \\
(72.7)\end{array}$ & $\begin{array}{l}26.02 \pm 2.43 \\
(45.9)\end{array}$ \\
\hline & 4.0 & $22.37 \pm 1.17$ & $2.25 \pm 0.07$ & $5.92 \pm 0.30$ & $48.98 \pm 8.60$ & $\begin{array}{l}7.63 \pm 1.34 \\
(34.0)\end{array}$ & $\begin{array}{l}1.20 \pm 0.23 \\
(53.4)\end{array}$ & $\begin{array}{l}4.26 \pm 1.33 \\
(72.6)\end{array}$ & $\begin{array}{l}22.96 \pm 7.35 \\
(44.4)\end{array}$ \\
\hline & 6.5 & $19.59 \pm 1.31$ & $2.00 \pm 0.08$ & $4.34 \pm 1.25$ & $51.37 \pm 13.00$ & $\begin{array}{l}6.67 \pm 1.27 \\
(33.9)\end{array}$ & $\begin{array}{l}1.01 \pm 0.14 \\
(50.7)\end{array}$ & $\begin{array}{l}2.86 \pm 0.40 \\
(70.1)\end{array}$ & $\begin{array}{l}16.32 \pm 2.20 \\
(44.3)\end{array}$ \\
\hline \multirow{3}{*}{$\mathrm{MJ}$} & 2.0 & $34.84 \pm 5.08$ & $6.78 \pm 0.13$ & $\begin{array}{l}11.50 \\
1.27\end{array}$ & $191.56 \pm 4.57$ & $\begin{array}{l}27.68 \pm 7.23 \\
(78.7)\end{array}$ & $\begin{array}{l}5.04 \pm 0.52 \\
(74.3)\end{array}$ & $\begin{array}{l}7.57 \pm 1.86 \\
(65.3)\end{array}$ & $\begin{array}{l}87.89 \pm 0.35 \\
(45.9)\end{array}$ \\
\hline & 5.0 & $30.98 \pm 3.72$ & $6.77 \pm 0.24$ & $7.74 \pm 0.30$ & $178.80 \pm 7.18$ & $\begin{array}{l}21.36 \pm 8.17 \\
(67.8)\end{array}$ & $\begin{array}{l}4.31 \pm 1.03 \\
(64.0)\end{array}$ & $\begin{array}{l}4.39 \pm 1.42 \\
(56.4)\end{array}$ & $\begin{array}{l}69.75 \pm 6.00 \\
(39.1)\end{array}$ \\
\hline & 7.5 & $27.45 \pm 3.89$ & $6.29 \pm 1.31$ & $3.66 \pm 0.08$ & $\begin{array}{l}163.90 \\
16.70\end{array}$ & $\begin{array}{l}16.99 \pm 6.80 \\
(60.7)\end{array}$ & $\begin{array}{l}3.50 \pm 0.23 \\
(57.3)\end{array}$ & $\begin{array}{l}1.85 \pm 0.57 \\
(50.4)\end{array}$ & $\begin{array}{l}57.73 \\
13.00 \\
(35.0)\end{array}$ \\
\hline \multirow{3}{*}{$\mathrm{R}$} & 2.0 & $24.52 \pm 0.76$ & $3.24 \pm 0.27$ & $4.05 \pm 0.80$ & $51.80 \pm 10.30$ & $\begin{array}{l}8.94 \pm 2.30 \\
(36.6)\end{array}$ & $\begin{array}{l}3.02 \pm 0.70 \\
(92.8)\end{array}$ & $\begin{array}{l}3.67 \pm 1.80 \\
(87.9)\end{array}$ & $\begin{array}{l}22.14 \\
11.50 \\
(42.6)\end{array}$ \\
\hline & 5.0 & $22.66 \pm 1.50$ & $2.04 \pm 0.14$ & $3.15 \pm 0.54$ & $45.40 \pm 6.70$ & $\begin{array}{l}8.74 \pm 1.69 \\
(37.7)\end{array}$ & $\begin{array}{l}1.93 \pm 0.16 \\
(95.7)\end{array}$ & $\begin{array}{l}2.96 \pm 1.45 \\
(91.1)\end{array}$ & $\begin{array}{l}22.32 \pm 8.37 \\
(49.2)\end{array}$ \\
\hline & 8.5 & $17.44 \pm 0.13$ & $1.97 \pm 0.24$ & $2.78 \pm 0.45$ & $33.75 \pm 6.84$ & $\begin{array}{l}5.77 \pm 1.35 \\
(33.1)\end{array}$ & $\begin{array}{l}1.67 \pm 0.42 \\
(84.1)\end{array}$ & $\begin{array}{l}2.30 \pm 1.16 \\
(80.6)\end{array}$ & $\begin{array}{l}13.43 \pm 6.05 \\
(39.8)\end{array}$ \\
\hline
\end{tabular}

